\title{
Morphology of small-scale submarine mass movement events across the northwest United Kingdom
}

\author{
Gareth D.O. Carter $^{\mathrm{a}, *}$, Rhys Cooper ${ }^{\mathrm{a}}$, Joana Gafeira ${ }^{\mathrm{a}}$, John A. Howe ${ }^{\mathrm{b}}$, David Long ${ }^{\mathrm{a}}$ \\ a British Geological Survey, The Lyell Centre, Research Avenue South, Edinburgh EH14 4AP, UK \\ b Scottish Association for Marine Science, Scottish Marine Institute, Dunbeg, Oban PA37 10A, UK
}

\section{A R T I C L E I N F O}

\section{Article history:}

Received 14 February 2020

Received in revised form 26 May 2020

Accepted 29 May 2020

Available online 30 May 2020

\section{Keywords:}

Subaqueous mass movements

Morphometrics

Submarine landslides

Fjords

\begin{abstract}
A B S T R A C T
A review of multibeam echo sounder (MBES) survey data from five locations around the United Kingdom northwest coast has led to the identification of a total of 14 separate subaqueous mass movement scars and deposits within the fjords (sea lochs) and coastal inlets of mainland Scotland, and the channels between the islands of the Inner Hebrides. In these areas, Quaternary sediment deposition was dominated by glacial and glaciomarine processes. Analysis of the morphometric parameters of each submarine mass movement has revealed that they fall into four distinct groups of subaqueous landslides; Singular Slumps, Singular Translational, Multiple Single-Type, and Complex (translational \& rotational) failures. The Singular Slump Group includes discrete, individual subaqueous slumps that exhibit no evidence of modification through the merging of several scars. The Singular Translational Group comprise a single slide that displays characteristics associated with a single translational (planar) failure with no merging of multiple events. The Multiple Single-Type Group incorporates scars and deposits that displayed morphometric features consistent with the amalgamation of several failure events of the same type (e.g. debris flows or slumps). Finally, the Complex (translational \& rotational) Group comprises landslides that exhibited complex styles of failures, including both translational and rotational mechanisms controlling the same slide. The submarine mass movements that comprise this dataset are then discussed in relation to global fjordic and glaciomarine nearshore settings, and slope failure trigger mechanisms associated with these environments are described with tentative links to individual submarine landslides from the database, where appropriate. It is acknowledged that additional MBES data are needed not only to expand this database, but also in order to create a more statistically robust study. However, this initial study provides the basis for a much wider investigation of subaqueous mass movements and correlations between their morphometric parameters.

(c) 2020 British Geological Survey, a component body of UKRI. All Rights Reserved. \{BGS (c) UKRI 2020. All Rights Reserved\}. Published by Elsevier B.V. This is an open access article under the CC BY license (http://creativecommons.
\end{abstract} org/licenses/by/4.0/).

\section{Introduction}

Over previous decades, seabed scars created by submarine landslides have been identified across the United Kingdom Continental Shelf (UKCS), with the vast majority having occurred along the steeper slopes of the continental margin during the Pliocene - Pleistocene (Evans et al., 2005). For example, along the Atlantic continental margin of NW Europe, evidence of various mass movement events has been documented. These often large-scale failures can transport sediment volumes of up to $4000 \mathrm{~km}^{3}$ downslope and leave headwall scars of almost $400 \mathrm{~km}$ in length and $300 \mathrm{~m}$ high (Evans et al., 2005). Offshore of the United Kingdom (UK), these include the Miller Slide and Afen Slide of the West Shetland Shelf, and the Sula Sgeir Fan, the Geikie Slide and the Peach Slide Complex of the Hebrides Shelf (Baltzer et al.,

\footnotetext{
* Corresponding author.

E-mail address: gcarter@bgs.ac.uk (G.D.O. Carter).
}

1998; Bulat, 2005; Evans et al., 2005; Holmes et al., 1998; Jackson et al., 2004; Long et al., 2003).

Previous studies of mass movement deposits within the nearshore zone around the United Kingdom include a site located approximately 500-700 m offshore of Lyme Regis in Dorset, characterised by a hummocky, boulder-covered area of seafloor measuring approximately $1500 \mathrm{~m}$ by $700 \mathrm{~m}$ and interpreted as being the preserved remains of a coastal landslide originating from a paleo cliff-line (Gallois, 2011). Other similar studies have focused on subaerial coastal landslides where the mass movement runout has propagated offshore, beneath present-day mean low waters (e.g. (Ballantyne et al., 2018)). However, these mass movement events are all associated with onshore coastal erosion, and not purely subaqueous mass failure. Despite the welldocumented examples of submarine slope failures mentioned above, very little evidence of nearshore subaqueous mass movements has been published from coastal waters around the United Kingdom. Perhaps the only exception is the work of Stoker et al. (Stoker et al., 2010) which details the various submarine landslide types present 
within Little Loch Broom in NW Scotland, including translational, rotational and complex failures, as well as small-scale Holocene debris flows across the slopes of the mouth and inner loch. Stoker et al. (Stoker et al., 2010) concluded that the majority of these slope failures occurred around 14-13 ka BP, most likely in response to deglaciation and associated seismic activity driven by glacio-isostatic unloading.

Aside from Stoker et al. (Stoker et al., 2010), the lack of published evidence of submarine slope failures in NW Scotland (UK) is rather surprising considering the similarities (both in morphology and Quaternary environments) between these sea lochs and the fjords of Norway, Alaska and Canada where submarine landslides have occurred in recent times (e.g. (Bøe et al., 2004; Hampton et al., 1996; Lee et al., 2006; Locat et al., 2003)). Such events within fjordic environments have proven to be highly destructive to both life and infrastructure. Damage to subsea cables and pipelines has been directly linked with subaqueous mass flows (e.g. (Carter et al., 2014)) with L'Heureux et al. (L'Heureux et al., 2010) reporting multiple cable breaks due to sediment slope failures in the Bay of Trondheim in Central Norway. Coastal infrastructure can also be at risk from mass wasting of submarine slopes within fjords. For example, the 1996 Finneidfjord landslide in northern Norway not only resulted in four fatalities, but also significant damage to waterfront housing and roads due to retrogressive failure of the submerged slopes as the headwall retreated upslope (Longva et al., 2003). In the most extreme events, submarine landslides within narrow, confined fjords have a tsunamigenic potential, proving hazardous to both life and coastal infrastructure. In 1964 retrogressive landsliding, following the Great Alaska earthquake, propagated onshore resulting in the collapse of harbour infrastructure and waterfront developments in the coastal towns of Seward and Valdez before tsunamis generated by the subaqueous mass movements inundated these and other coastal areas in the region leading to 43 fatalities (Hampton et al., 1996; Lee et al., 2006; Parsons et al., 2014). Similar tsunamigenic coastal landslides have been documented more recently, include the 2014 event at Statland, Norway, which caused considerable damage to the village (Glimsdal et al., 2016).

Given the potentially devastating consequences of shallow submarine landslides it is imperative that we understand potential slope stability issues within the shallow marine coastal regions of the UK. In particular, our lack of knowledge regarding the nature of the seabed within the fjords and inlets of Scotland is concerning given that these sea lochs have similar morphological features and settings to the global examples described above where recent slope failures have had such highly devastating results. These examples also demonstrate the temporal aspect to these events, highlighting that they are caused by active modern processes and therefore represent contemporary geohazards. In addition, previous studies (e.g. (Clare et al., 2018)) have highlighted that there tends to be a scale bias towards the mapping and reporting of large-scale events, and there is a requirement for studies that focus on small-scale $\left(\leq 1 \mathrm{~km}^{3}\right)$ mass movements which can still have damaging consequences on seafloor infrastructure.

In this paper we present the results of the morphometric analysis (following the methods of (Clare et al., 2018)) from five coastal inlets and sea lochs across NW Scotland (UK) where evidence of small-scale shallow submarine mass movement events has been observed on the seabed. Trends and correlations within the morphometrics dataset are then explored, followed by the wider implications for coastal infrastructure planning across both former and contemporary glaciomarine coastlines globally.

\section{Geological and environmental setting}

The coastline of NW Scotland is dominated by rugged, often steep bedrock slopes and cliffs that have been deeply incised landwards to form a series of channels, coastal inlets and sea lochs (fjords). The geometries of these confined bays have been greatly enhanced by Pleistocene glaciation, and can be up to $30 \mathrm{~km}$ in length from the mouth to the steep-fronted delta at the head, with water depths in excess of $150 \mathrm{~m}$ (Stoker et al., 2009). Major NW-SE-trending bedrock faults act as structural controls on the geometry of many of the fjords, although NE-SW orientated fjords are present along the coast of the mainland to the south of the Isle of Skye and are controlled by faults associated with the Caledonian trend (Stoker et al., 2009).

The Pleistocene glacial history of western Scotland has heavily influenced the seafloor morphology across the wider region. During the Last Glacial Maximum (LGM), the Hebrides Ice Stream (HIS), comprising the merged ice sheets from mainland Scotland, and the Islands of Mull and Skye, flowed west across the Malin and Hebrides Sea to the edge of the continental shelf where it fed the Barra-Donegal Fan until ice margin retreat began around 24-23 ka (Arosio et al., 2018; Dove et al., 2015). As the ice stream retreated, one lobe withdrew across the Malin Shelf with seabed glacial landforms signifying retreat back into the fjords of western Scotland (Arosio et al., 2018; Dove et al., 2015). Even after the onset of full deglaciation, these fjords experienced localised glacial conditions as recently as $12.8-11.5$ ka during the Younger Dryas (Howe et al., 2015).

Unfortunately, detailed stratigraphic logs are not available for all five locations where subaqueous mass movement deposits have been documented. However, the most landslide-proximal sediment cores from the British Geological Survey (BGS) Marine Geoscience Data Collection were reviewed as a means of assessing the subsurface stratigraphy for the area surrounding each mass movement scar. The examples of seafloor and subsurface stratigraphy detailed below provide an insight into typical sediment compositions and processes encountered within sea lochs of the Inner Hebrides Islands and west coast of mainland Scotland.

Evidence of glacial and post-glacial deposition can be found in many of the west coast sea lochs, inlets, and channels. Howe et al. (Howe et al., 2002) report on sediment cores taken from within Loch Etive which is connected to the Sea of the Hebrides through Loch Linnhe and the Firth of Lorn. The olive sandy silt and grey muddy sands encountered in this sea loch are interpreted as being of glaciomarine in origin, with overlying watery organic-rich, occasionally gassy, sandy muds and muddy sands representing younger river-derived sediments. This sequence is typical of the sea lochs adjoining the Firth of Lorn, where thick sequences of gassy muds are commonly pitted with pockmarks indicating fluid or gas flow at the seabed surface (Howe et al., 2015). Similarly, further north in the sea lochs of the Summer Isles region, where abundant evidence of glacial landforms can be observed, a Holocene lag of sand, mud and gravel containing lithic clasts and shell debris often drapes the shelly, organic-rich silty clays of the Holocene Summer Isles and Lateglacial Assynt Glaciogenic Formations (Stoker et al., 2006; Stoker et al., 2010). The seafloor within these sea lochs frequently exhibits pockmark hollows, with acoustic blanking and turbidity associated with shallow biogenic gas accumulation being a common feature of seismic profiles acquired from the Summer Isles region (Stoker et al., 2006). Away from the mainland, Dix and Duck (Dix \& Duck, 2000) described coarse sands and gravels which they interpreted as being glacigenic diamictons associated with the Ainort Glacier which occupied Loch Ainort on the Isle of Skye. These glacigenic deposits are overlain by decimetre to metres thick subaqueous debris flow deposits, consisting of poorly sorted sandy muddy gravels, which are in turn draped by fine-grained homogeneous sediments deposited under fjordic conditions (Dix \& Duck, 2000).

Dove et al. (Dove et al., 2015) provide an overview of the geology of the seafloor across the wider Inner Hebrides region. Prominent stratigraphic units that outcrop at seabed include the Late Weichselian - Holocene Jura and Barra Formations, with radiocarbon dating confirming an age of $\sim 16 \mathrm{ka}-10 \mathrm{ka}$ for the Jura Formation (Dove et al., 2015; Peacock et al., 2012). This unit typically comprises very soft to firm silty clays with occasional pebbles and shell fragments, and is thought to have been deposited under dynamic glaciomarine and marine conditions (Dove et al., 2015; Fyfe et al., 1993). The silty clays of the Barra Formation contain dropstones and are interpreted as having been 
Table 1

Summary of available multibeam (MBES) data and data sources.

\begin{tabular}{|c|c|c|c|c|}
\hline Location & Data provider & Date of survey & Resolution & MBES equipment \\
\hline Loch Eriboll & British Geological Survey (BGS) & 2010 & $1 \times 1 \mathrm{~m}$ grid & Kongsberg EM3002D \\
\hline Little Loch Broom & British Geological Survey (BGS) & 2005 & $5 \times 5 \mathrm{~m}$ grid & Geoacoustics GeoSwath system \\
\hline Sound of Mull & Maritime and Coastguard Agency (MCA) & 2011-2012 & $2 \times 2 \mathrm{~m}$ grid & Kongsberg EM3002D and EM2040 \\
\hline Firth of Lorn & Scottish Association for Marine Science (SAMS) & 2012 & $5 \times 5 \mathrm{~m}$ grid & Reson 7125 and Kongsberg EM3002D \\
\hline Holy Loch & British Geological Survey (BGS) & 2007 & $1 \times 1 \mathrm{~m}$ grid & Kongsberg EM3002D \\
\hline
\end{tabular}

deposited rapidly under glaciomarine conditions following the Late Weichselian glacial maximum (Dove et al., 2015; Fyfe et al., 1993). Fluid-escape features, such as seafloor pockmarks, are evident across much of the wider Sea of the Hebrides (Howe et al., 2012).

Present-day sedimentation across the region typically consists of reworked sediments from underlying Pleistocene glacial deposits, driven by tidal currents and wave action, although there is also a contemporaneous input from calcareous shell debris (Farrow, 1983; Howe et al., 2012). Many glacially overdeepened, steep-sided troughs and basins contain thick accumulations of muddy sands, originating from reworked glacial diamictons and outwash deposits, whereas shallower coastal slopes often exhibit a veneer of gravel lag, at or near the seabed surface (Farrow, 1983).

\section{Data and methods}

For the purposes of this study, a dataset consisting of multibeam echo sounder (MBES) data collected from five nearshore and coastal sites across NW United Kingdom was collated from various sources (Table 1). These surveys were undertaken over a period of seven years (2005-2012) using a variety of MBES systems, including Kongsberg EM3002D and EM2040, Reson 7125, and a Geoacoustics GeoSwath (Table 1). As MBES data was often delivered by data providers as processed ArcGIS gridded bathymetry layers, the resolution of the data was predetermined by the requirements of the data provider and therefore varied from $1 \mathrm{~m}$ to $5 \mathrm{~m}$ grids. Seismic (boomer) profiles were only available for a very limited number of sites, typically with only a single seismic line available per landslide and, as a result, have been used purely as additional supporting evidence where present. Backscatter data were also consulted, where available, however these data were either too low quality to be of significant use to the study or simply did not add any new insights into the relative timings of failure events and as a result do not feature as a dataset in this study.

This dataset was examined for features indicative of mass movement events, and quantitative data (e.g. slope angle, deposit length, scar perimeter length) were extracted through an ArcGIS (Esri software) platform. The set of morphometric parameters determined from the MBES dataset were established using the methodology of Clare et al. (Clare et al., 2018), and were recorded in a database with a subset of key parameters provided in Table 2 and all parameters included in individual mass movement morphometrics figures (Figs. 4-13). In some instances, Fledermaus software was used purely for visualisation purposes and, where it was felt that Fledermaus images better highlighted the key morphometric parameters of the mass movement scar and deposit, this was used for the creation of some figures. In general, tools and methods for extracting these key morphometric parameters are readily available in ArcGIS toolboxes. However, a tool for establishing the volume of sediment evacuated by each individual mass flow was not available and was therefore devised based on the approach proposed by ten Brink et al. (Ten Brink et al., 2006)

Table 2

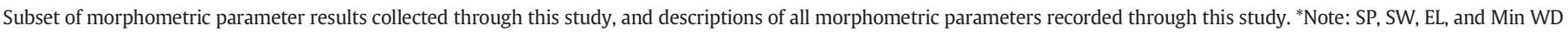

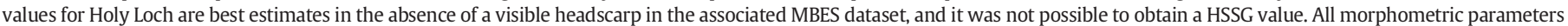
are presented on figures for individual mass movements (Figs. 4-13).

\begin{tabular}{|c|c|c|c|c|c|c|c|c|}
\hline Name & Group & $\mathrm{SP}(\mathrm{m})$ & $\mathrm{SW}(\mathrm{m})$ & $\mathrm{EL}(\mathrm{m})$ & $\operatorname{HSSG}\left({ }^{\circ}\right)$ & $\mathrm{SG}\left({ }^{\circ}\right)$ & Min WD (mbsl) & Volume $\left(\mathrm{m}^{3}\right)$ \\
\hline Rireavach & Complex (T\&R) & 4108 & 495 & 396 & 19.75 & 4.46 & 31 & - \\
\hline Badcaul & Complex (T\&R) & 2953 & 800 & 1300 & 20.54 & 4.6 & 28 & - \\
\hline Loch Eriboll & Multiple Single-Type & 1735 & 776 & 93 & 48 & 12 & 8 & - \\
\hline Carnach & Multiple Single-Type & 730 & 180 & 300 & 13.45 & 9.61 & 28 & 78,603 \\
\hline Scoraig & Multiple Single-Type & 1414 & 530 & 210 & 22.72 & 4.7 & 34 & 521,764 \\
\hline SoM_4 & Multiple Single-Type & 737 & 362 & 176 & 49.34 & 32.76 & 85 & 456,009 \\
\hline SoM_1 & Singular Slump & 458 & 100 & 207 & 51.54 & 24.1 & 117 & 106,807 \\
\hline SoM_2 & Singular Slump & 259 & 55 & 179 & 39.27 & 23.01 & 124 & 26,752 \\
\hline SoM_3 & Singular Slump & 285 & 80 & 187 & 47.1 & 30.18 & 116 & 52,380 \\
\hline SoM_5 & Singular Slump & 297 & 72 & 125 & 39.2 & 23.39 & 132 & 22,026 \\
\hline SoM_6 & Singular Slump & 365 & 66 & 155 & 49.41 & 24 & 122 & 43,186 \\
\hline Kerrera & Singular Slump & 477 & 150 & 190 & 39.15 & 21.53 & 67 & 131,038 \\
\hline OLS & Singular Slump & 431 & 241 & 190 & 9.19 & 2.26 & 32 & - \\
\hline Holy Loch & Singular Translational & 521 & 326 & 82 & - & 8.73 & 11 & 39,141 \\
\hline
\end{tabular}

Morphometric parameter descriptions (after (Clare et al., 2018))

DL Deposit Length - maximum length of the slide deposit, excluding outrunner blocks.

DT Deposit Thickness - maximum deposit thickness, as calculated from multibeam data (i.e. maximum elevation gain across the deposit surface when compared with the bathymetric values for the surrounding seafloor).

DW Deposit Width - maximum deposit width, approx. Orthogonal to the Deposit Length.

EL Evacuated Length - maximum length of evacuated surface, from headscarp to maximum upslope extent of the landslide deposit.

HSSG Headscarp Slope Gradient - Maximum slope gradient from slope profiles across the extent of the headscarp.

SG Slope Gradient - maximum slope gradient from slope profiles across undisturbed slopes adjacent to the failure scar.

SP Scar Perimeter - length of scar perimeter including headscarp and side scarps.

SW Scar Width - maximum scar width.

TL Total Length - total length of the mappable landslide scar and deposit, from upslope limit of the headscarp to the maximum downslope extent of the deposit (excluding outrunner blocks). Should be equal to EL + DL.

WD Water Depth - bathymetric values for both the shallowest point of the headscarp (Min WD) and the deepest point of the deposit toe (Max WD).

Volume Volume - Estimation of evacuated material. In this study, this has been undertaken using multibeam bathymetry due to the lack of high-quality seismic. See Data \& Methods for further details. 


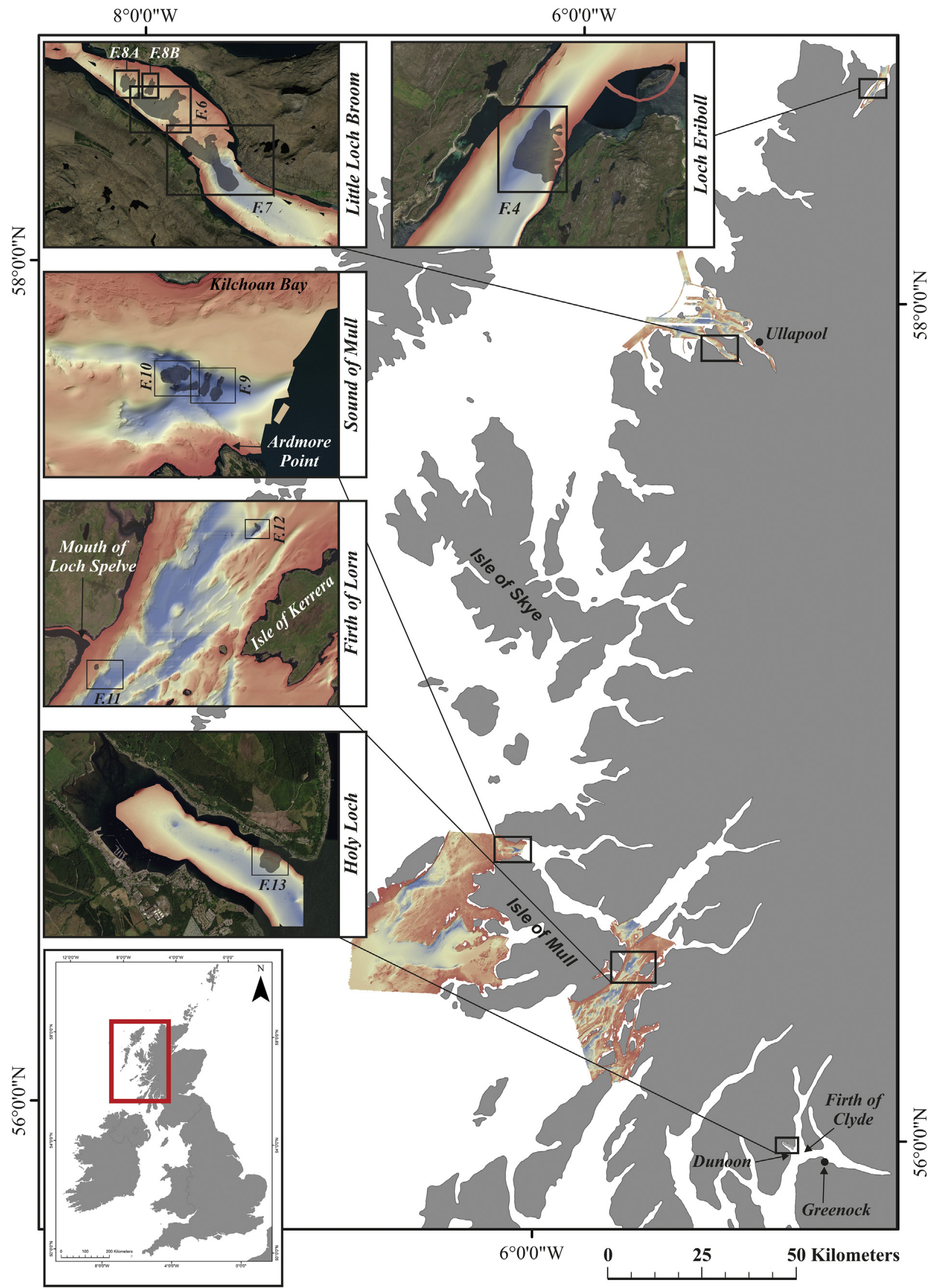

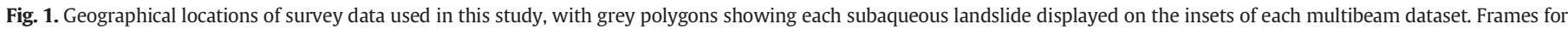

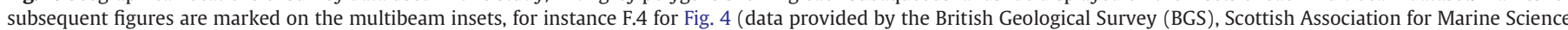
(SAMS), and the UK Hydrographic Office (UKHO)/Maritime and Coastguard Agency (MCA)). 


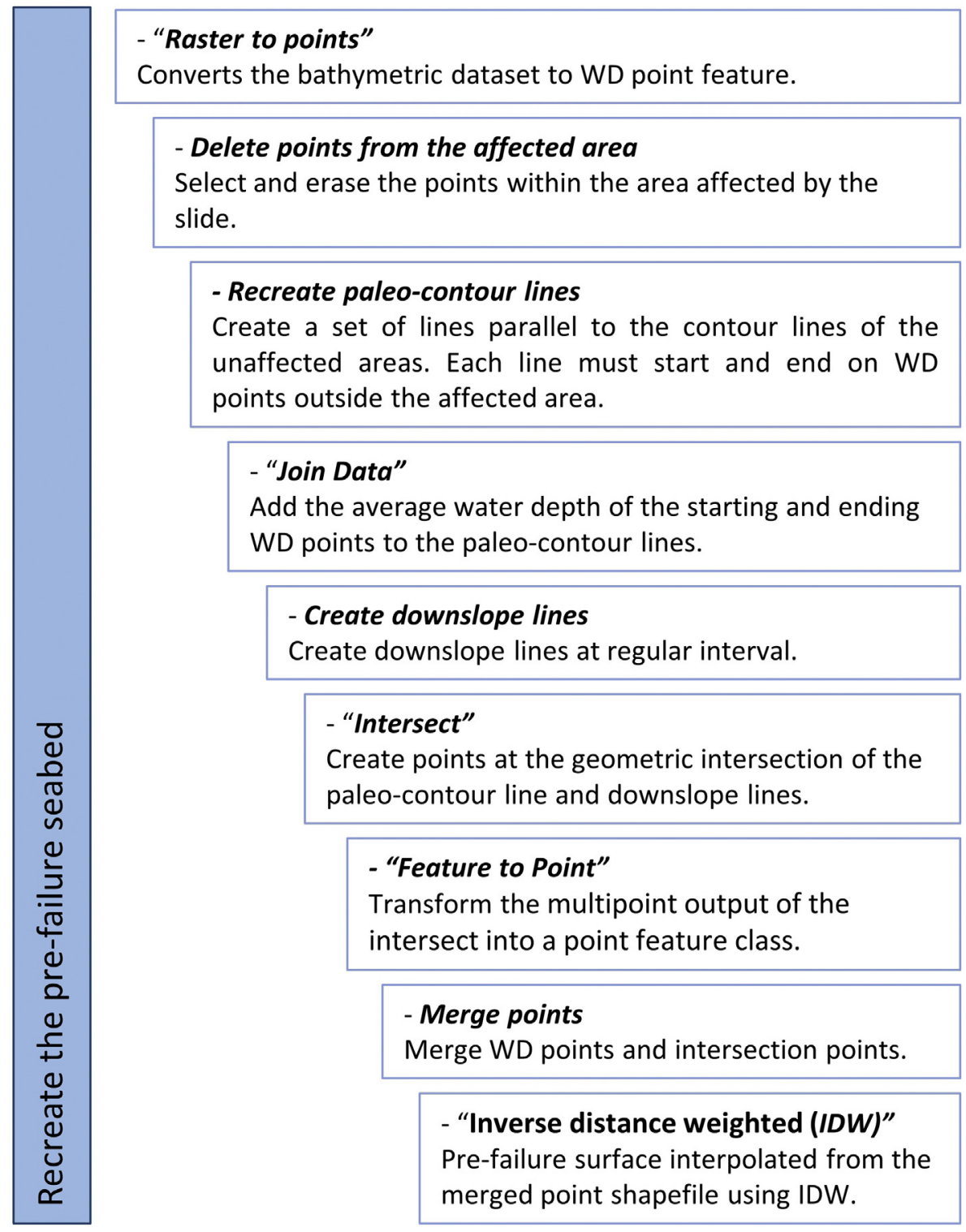

\begin{tabular}{|c|c|}
\hline$\frac{\mathscr{E}}{\frac{E}{ٍ}}$ & $\begin{array}{l}\text { - "Minus" } \\
\text { Subtract the original raster to the recreated pre-failure seabed } \\
\text { using the Raster Calculator or Minus Tool }\end{array}$ \\
\hline 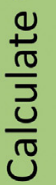 & $\begin{array}{l}\text { - "Surface volume" } \\
\text { Calculate the volume between the minus surface and the } \\
\text { reference plane. For calculating the volume missing, the } \\
\text { reference plane used was below }-0.5 \mathrm{~m} \text {. }\end{array}$ \\
\hline
\end{tabular}

Fig. 2. Workflow diagram showing the process used to calculate evacuation volumes.

for calculating volumes based solely on MBES data. This method combines multiple ArcGIS geoprocessing tools to calculate the volume of material removed from the scar area of the mass flow (Figs. 2 and 3). This two-stage approach firstly generates a synthetic pre-failure surface. The difference between this pre-failure surface and the present-day bathymetry is then used to calculate the volume of displaced material.

To recreate the pre-failure morphology of the seabed, the bathymetry raster was first converted into water depth (WD) points using the
"Raster to points" tool (Fig. 3C). The WD points within the area affected by the slide were then selected and erased. A set of polylines parallel to the contour lines of the undisturbed areas were then created to reconstruct the paleo-contour lines across the area prior to failure (Fig. 3D). The start and end of each polyline must overlap a WD point located outside the evacuation scar. The "Join Data" tool was then used to add the average water depth of the start and end WD points to these prefailure paleo-contour lines. A set of downslope polylines were then 

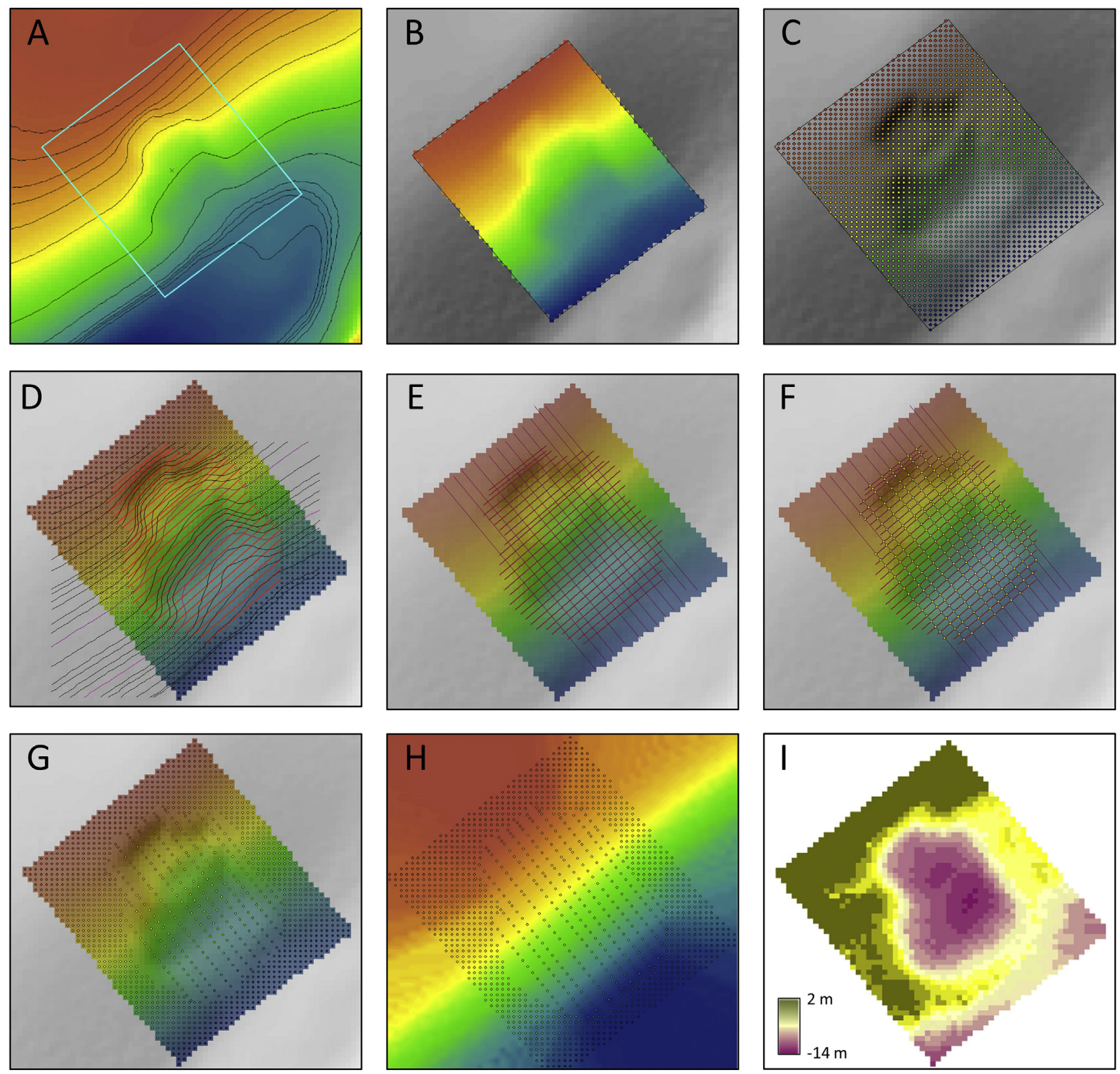

Fig. 3. Graphical representation of the process used to calculate evacuation volumes.

generated at regular intervals (Fig. 3E), followed by the creation of a shapefile containing the intersection points of these downslope lines with the paleo-contours using the "Intersect" tool (Fig. 3F). These multipoint output data were then transformed into a point feature class using the "Feature to Point" tool and then merged with the WD points using the "Merge" tool (Fig. 3G). The resultant merged feature class was used to create a pre-failure surface using the Inverse Distance Weighted interpolation (IDW) tool (Fig. 3H). To estimate the volume of material removed from the scar area, the original raster is subtracted from the calculated artificial pre-failure seabed surface using the "Raster Calculator" or "Minus" Tool (Fig. 3I). The "Surface volume" tool was then used to calculate the volume between the resulting surface and a reference plane (below $-0.5 \mathrm{~m}$ ).

This approach assumes the ability to use the undisturbed area surrounding the slide to recreate the pre-failure slope surface across the failure. However, the MBES datasets do not always cover the full extent of the mass flow as water depths in nearshore settings may be too shallow for most traditional bathymetric survey methods and too deep for land-based surveys to be effective. Furthermore, in some cases, even with full data coverage, it is impossible to use the undisturbed surrounding slopes to recreate a valid pre-failure surface due to the morphological complexity of the modified slope. In such cases, it may be required to increase the degree of interpretation to create curved paleo-contour lines. Due to the implicit subjectivity required to recreate the pre-failure surface in complex settings or the lack of sufficient MBES coverage, we only calculate the volume of removed material for ten of the 14 slides studied.

Sediment core logs from the BGS Marine Geoscience Data Collection were reviewed and any quantitative data relating to the physical characteristics and composition of the sediments (e.g. Folk sediment classification, shear strength) forming the slopes where the failures occurred were recorded.

By combining the results of the analysis outlined above into a single database it has been possible to draw a number of conclusions regarding the individual types and collective groups of landslides (e.g. translational, rotational, debris flow, complex/compound), and the presence of any morphological trends within the dataset. The various landslide types and groups are loosely based upon the Hungr et al. (Hungr et al., 
2014) classification scheme; note that the terms translational and planar have been used interchangeably throughout this study.

\section{Morphology of coastal subaqueous landslides}

The morphological characteristics of subaqueous mass movements at five locations across NW Scotland (UK) were analysed and quantitative data compiled to inform on landslide type and provide key morphometric parameters (e.g. scar perimeter, evacuated volume) for each group. The results of this analysis are described below and a subset of key parameters are summarised in Table 2 . All morphometric parameters are annotated on the figures throughout the following section.

\subsection{Morphometrics of Loch Eriboll mass flows}

Loch Eriboll is located on the northern coastline of Scotland (Fig. 1), and is an approximately $16 \mathrm{~km}$ long NE-SW orientated fjord, with water depths reaching up to $63 \mathrm{~m}$ below sea level (mbsl). The observed slope failures occur along a west-facing $\mathrm{N}-\mathrm{S}$ trending slope.

At a minimum water depth of approx. $8 \mathrm{mbsl}$, a $1735 \mathrm{~m}$ long sequence of connected scars is observed in the MBES dataset, measuring approximately $776 \mathrm{~m}$ across at the widest point (Fig. 4). The headscarp is up to $11 \mathrm{~m}$ high and has a maximum slope gradient of $48^{\circ}$, compared with a maximum slope gradient of $12^{\circ}$ from adjacent, undisturbed slopes. The scar encompasses a series of incised gullies that exhibit a stepped basal profile, with the step ridges running roughly parallel to the slope contours. The maximum length of the evacuated gullies is approximately $93 \mathrm{~m}$, at which point the deposit can be traced for a further $595 \mathrm{~m}$ into the bathymetric trough of the fjord, to $54 \mathrm{mbsl}$.

The deposit rises approximately $4 \mathrm{~m}$ above the surrounding seafloor, however sub-bottom data suggests greater thicknesses may be present across localised sections of the deposit (Fig. 5a). There appears to be the amalgamation of several debris lobes emanating from the incised gullies, with raised ridges running orthogonal to the slope contours bounding hummocky, laterally discontinuous raised crests that are orientated sub-parallel to the base of the slope. The complex lateral modification of the slope caused by this series of connected mass flows prevented the recreation of the pre-failure slope surface with an acceptable degree of confidence, and therefore a volume of displaced sediment could not be ascertained at this location.

\subsection{Morphometrics of Little Loch Broom slope failures}

Evidence of several subaqueous slope failures have been observed in the Little Loch Broom with names being assigned to each mass movement event based on Stoker et al. (Stoker et al., 2010); the Rireavach Slide, Badcaul Slide, Carnach Slide, and Scoraig Slide. Little Loch Broom is a NW-SE orientated fjord located approximately $5 \mathrm{~km}$ southwest of the town of Ullapool (Fig. 1), measuring $12 \mathrm{~km}$ in length and up to $2 \mathrm{~km}$ in width, with the mouth of the fjord opening out into The Minch (Stoker et al., 2009).

\subsubsection{Rireavach Slide}

The Rireavach Slide comprises a 4108 m laterally continuous headscarp, located at a minimum water depth of $31 \mathrm{mbsl}$, incised into the southwest facing, NW-SE trending slopes. The slide propagates into the central area of the fjord from a bathymetric high formed by a mid-loch bedrock sill which is capped by a moraine (Fig. 6). While the surrounding, undisturbed slopes have a maximum gradient of $4.5^{\circ}$, the $10 \mathrm{~m}$ high headscarp has a steeper inclination of $20^{\circ}$. At its widest point, the scar measures $495 \mathrm{~m}$ and the evacuation zone extends for approximately $396 \mathrm{~m}$ downslope.

The scar has two distinct rectilinear points of failure; one incised into the northern slope and a second abutting the mid-loch moraine, termed the northern re-entrant and eastern re-entrant respectively by Stoker et al. (Stoker et al., 2010). Small-scale slumping along the headscarp has resulted in the development of multiple scalloped indentations which modify the rectilinear scar into a crenulated break in slope. The mass movement deposit can be traced from the area of the evacuation scar into the base of the fjord ( $75 \mathrm{mbsl}$ ) and along the strike of the basin for approximately $1344 \mathrm{~m}$. The seafloor expression of the deposit is that of a gently undulating surface, perhaps in part due to the Holocene lag deposits overlying the inclined laminated clays comprising the transported slope material (Stoker et al., 2010). However, previous studies have shown the mass movement deposit to be up to $12 \mathrm{~m}$ in thickness (e.g. (Stoker et al., 2010)).

Unfortunately, due to the extensive degree of slope modification across this mass movement scar, whereby the pre-failure lower slope in particular was modified to such an extent that the recreation of a synthetic pre-failure surface could not be achieved to a reliable degree of certainty, a displaced sediment volume could not be calculated at this locality.

\subsubsection{Badcaul Slide}

The approximately $2953 \mathrm{~m}$-long scar of the Badcaul Slide is situated on the southeast facing slope of the mid-loch sill, with the failed material transported from the $10 \mathrm{~m}$ high headscarp located at a minimum water depth of $28 \mathrm{mbsl}$ to a depth of $112 \mathrm{mbsl}$ across the inner loch basin (Fig. 7). The headscarp has a maximum slope gradient of $20.5^{\circ}$, compared with $4.6^{\circ}$ gradient of surrounding undisturbed slopes, and at its widest point the scar measures $650 \mathrm{~m}$ in width. The scar comprises two major areas of failure, however the most westerly side scarp is not well defined on the MBES data (Fig. 7). The evacuated scar surface extends $1300 \mathrm{~m}$ downslope, at which point a hummocky surface can be observed on the MBES extending across the basin floor. Boomer profiles described by Stoker et al. (Stoker et al., 2010) show a chaotic debris lobe at the base of the excavated slope, which extends up to $800 \mathrm{~m}$ into the inner basin, but is eventually obscured on the seismic sub-bottom profile by gas blanking. Stoker et al. (Stoker et al., 2010) also reported that discrete laminated units could be observed beneath the evacuation surface, either tilted back into the slope or running subparallel to the slope surface and therefore dipping into the basin (Fig. 5b). It was not possible to recreate the pre-failure surface for the Badcaul Slide with a high degree of confidence due to the lack of bathymetric data for its westerly side scarp, and therefore a volume for displaced sediment could not be ascertained for this landslide.

\subsubsection{Scoraig Slide}

Approximately $1 \mathrm{~km}$ NW of the larger Rireavach Slide, along the southwest facing, NW-SE trending slope (maximum $4.7^{\circ}$ ) of the outer loch basin, a crenulated, undulating scar can be traced for $1414 \mathrm{~m}$ at a minimum water depth of 34 mbsl (Fig. 8a \& c). The headscarp gradient has a maximum dip of $22.7^{\circ}$, and measures up to $530 \mathrm{~m}$ alongslope and $210 \mathrm{~m}$ downslope. At the base of the scar, an undulating, hummocky surface can be observed forming a $2 \mathrm{~m}$ (maximum) bathymetric high above the surrounding basin floor. This mass movement deposit can be traced for $550 \mathrm{~m}$ along the central axis of the basin, extending $300 \mathrm{~m}$ from the evacuation scar across the seafloor. Following the creation of the synthetic pre-failure surface, a volume of $521,764 \mathrm{~m}^{3}$ of mobilised sediment was calculated.

\subsubsection{Carnach Slide}

Along a steeper $\left(\max 9.6^{\circ}\right.$ ) section of the outer loch basin, approximately halfway between the Scoraig and Rireavach Slides, a small (730 $\mathrm{m}$ long) seafloor depression is visible on the MBES data starting at a minimum water depth of $28 \mathrm{mbsl}$ (Fig. 8b \& d). Once again, this slope failure has developed on a southwest facing, NW-SE trending slope. The $5 \mathrm{~m}$-high headscarp has a maximum slope gradient of 

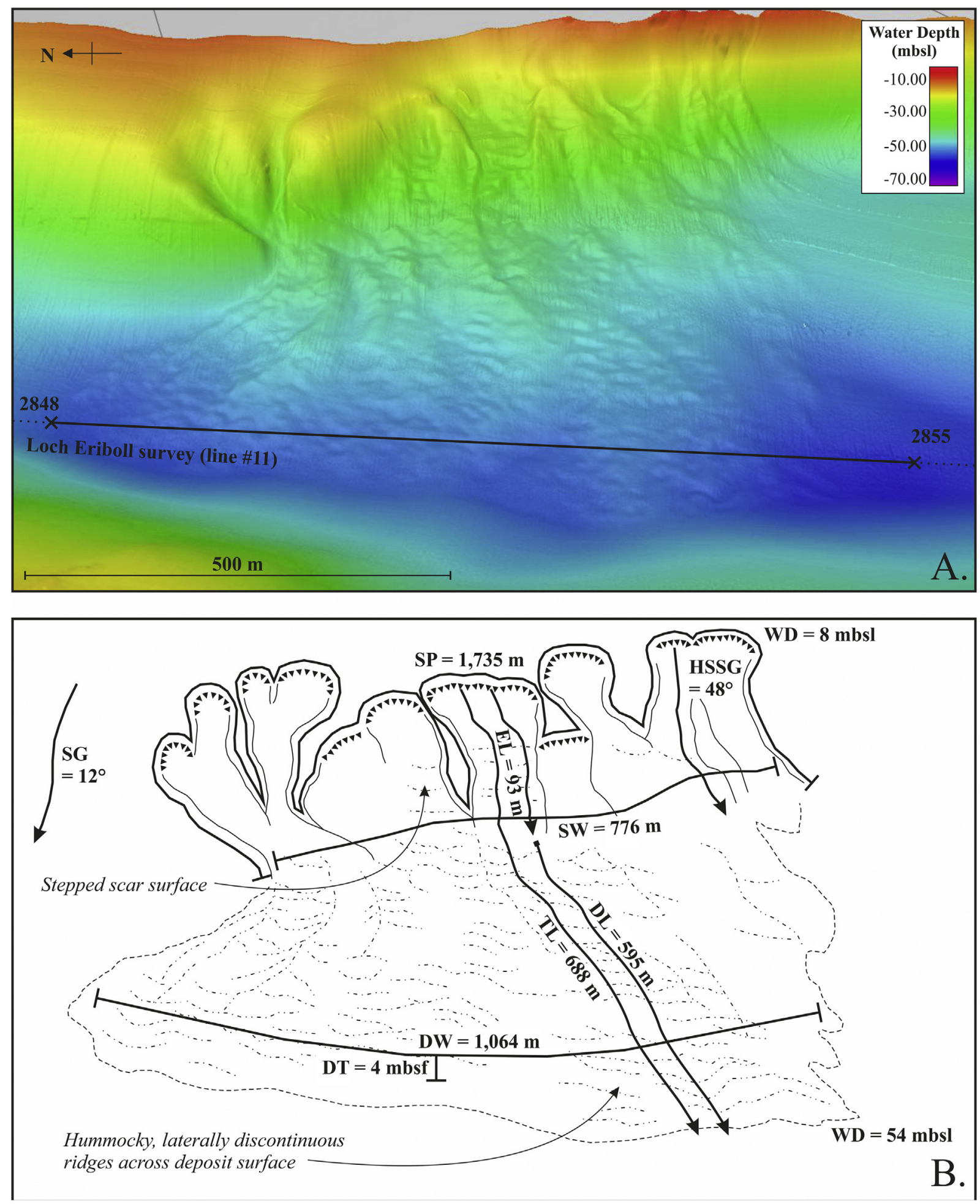

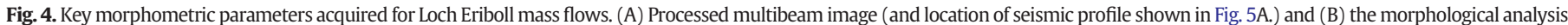

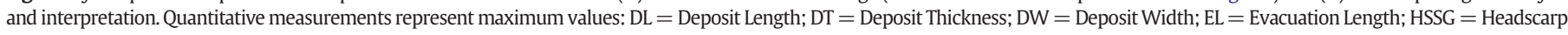

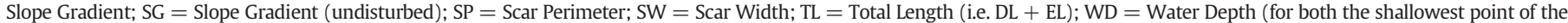
headscarp and the deepest point of the deposit toe).

$13.5^{\circ}$, and the evacuation surface measures $300 \mathrm{~m}$ downslope and $180 \mathrm{~m}$ alongslope at the widest point.

Emanating from the base of the scar are two discrete lobes rising up to $1.5 \mathrm{~m}$ above the surrounding slope, with the entire deposit measuring a maximum of $250 \mathrm{~m}$ in length and $270 \mathrm{~m}$ in width. The toe of the deposit, located at $60 \mathrm{mbsl}$, remains on the submerged northern slope of the fjord and runout has not transported the failed sediment to the outer loch basin floor (approximately $75 \mathrm{mbsl}$ ). For the Carnach Slide, a volume of $78,603 \mathrm{~m}^{3}$ was calculated.

\subsection{Morphometrics of Sound of Mull slides}

A total of six subaqueous mass movement scars have been recognised on the steep slopes of an approximately $200 \mathrm{~m}$ deep NW- 

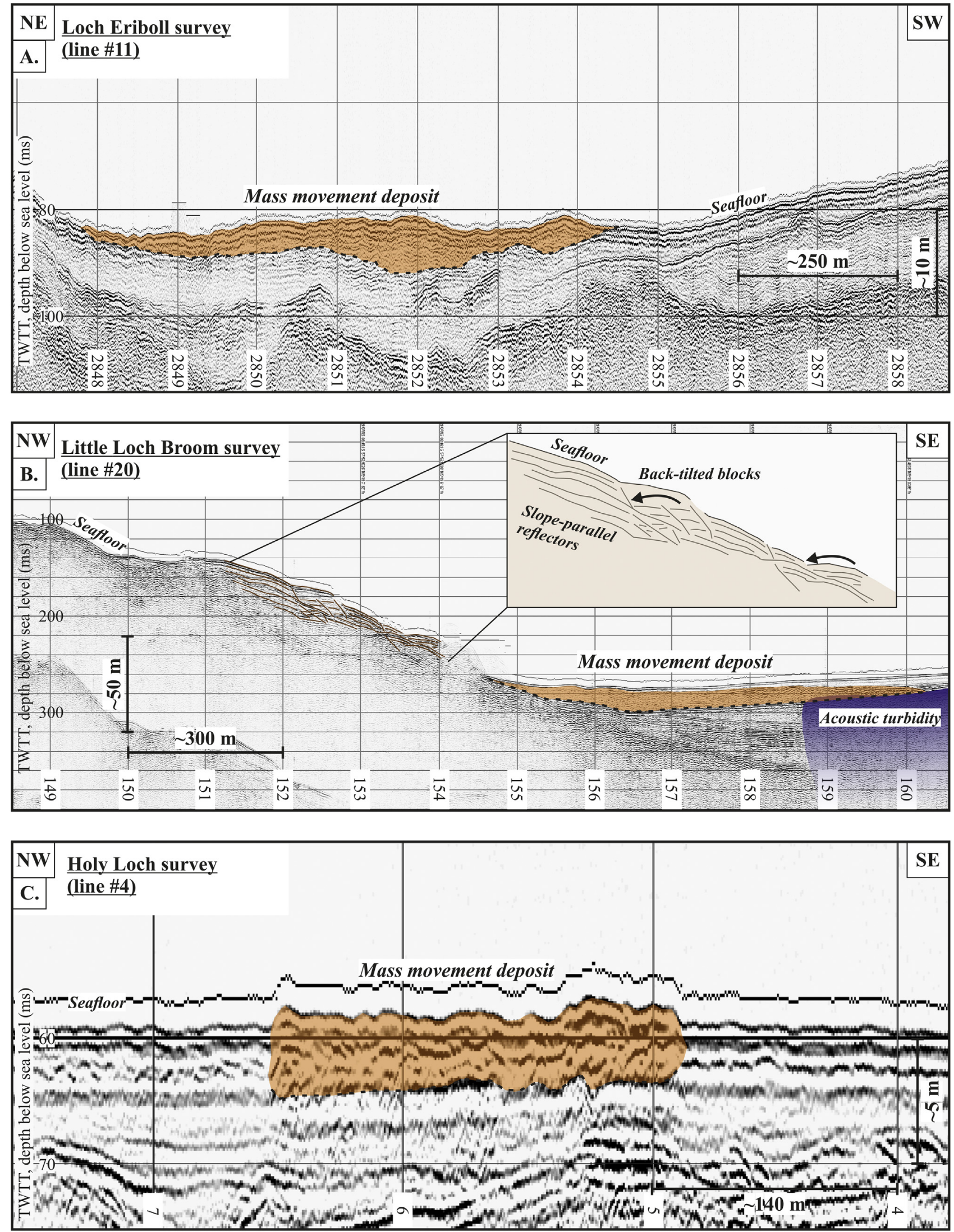

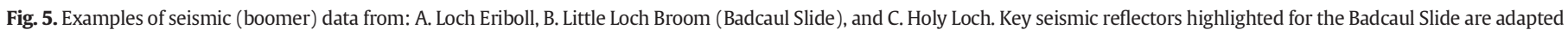
from (Stoker et al., 2010). For positions of seismic profiles, see Figs. 4A, 7A, and 13A respectively. 

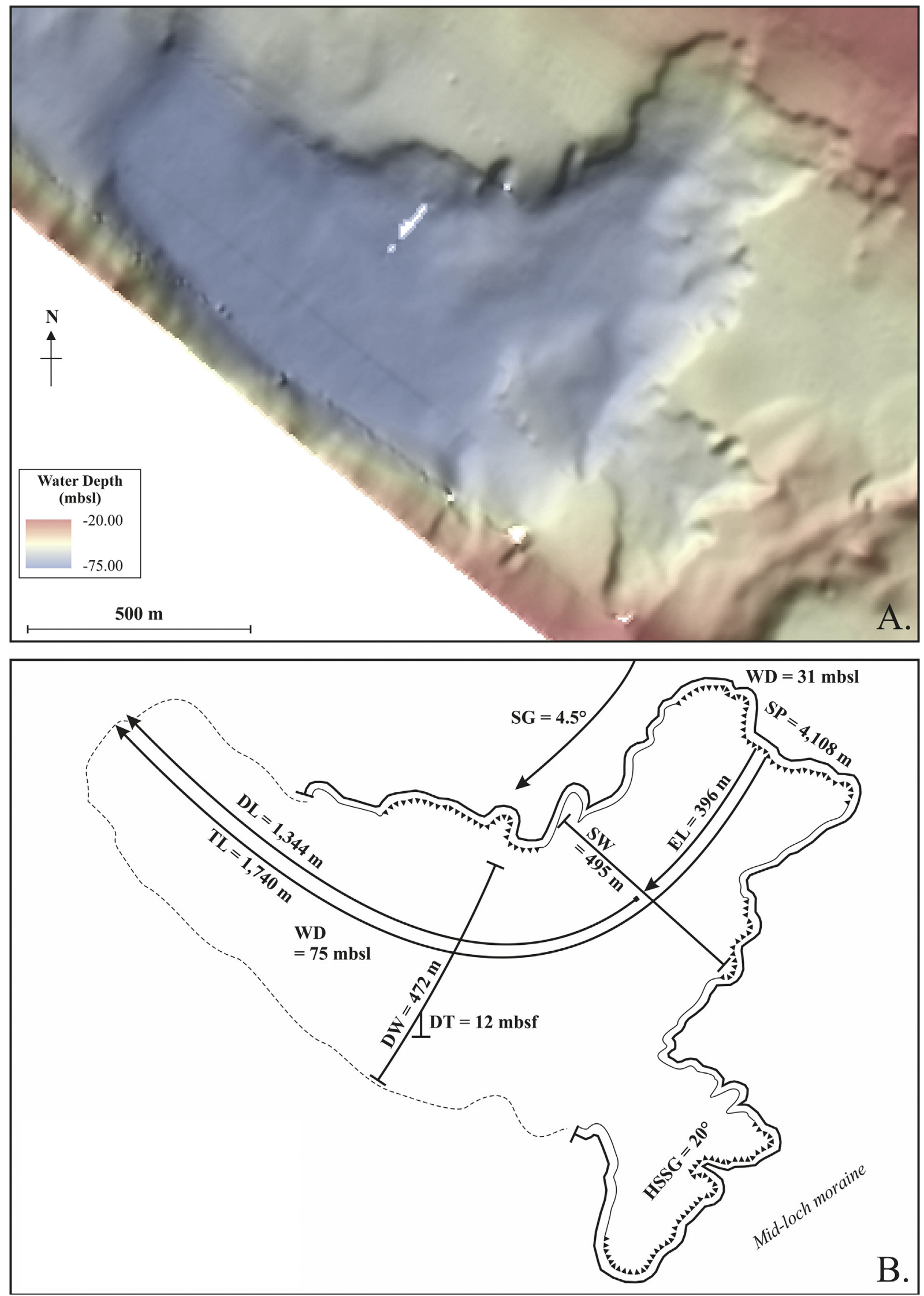

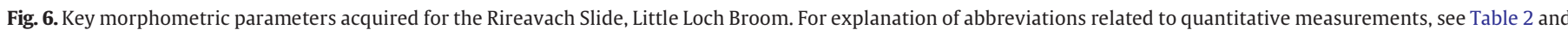
caption for Fig. 4. 

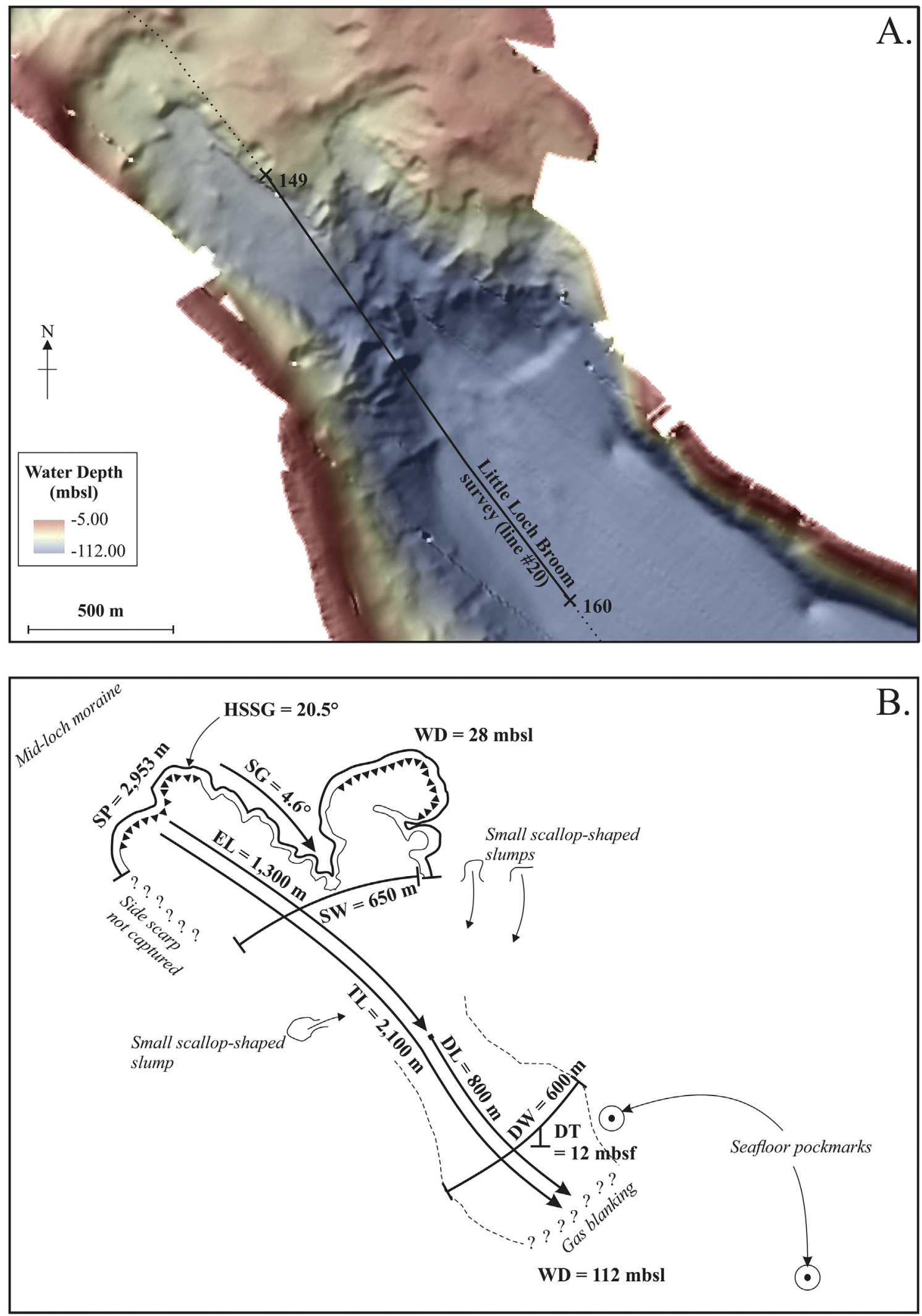

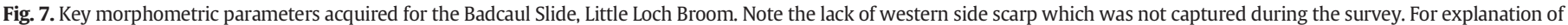
abbreviations related to quantitative measurements, see Table 2 and caption for Fig. 4.

SE orientated bathymetric trough separating the most northerly point of the Isle of Mull (Ardmore Point) and Kilchoan Bay on mainland Scotland (Fig. 1); three on the northeast slope and three along the southwest slope.
4.3.1. Northeast slope Sound of Mull, slides 1-3

Three discrete scars observed on the MBES dataset (minimum water depth of $116 \mathrm{mbsl}$ ) incised into the southwest facing, NW-SE trending slope have a measured perimeter length of between 259 and $458 \mathrm{~m}$ 

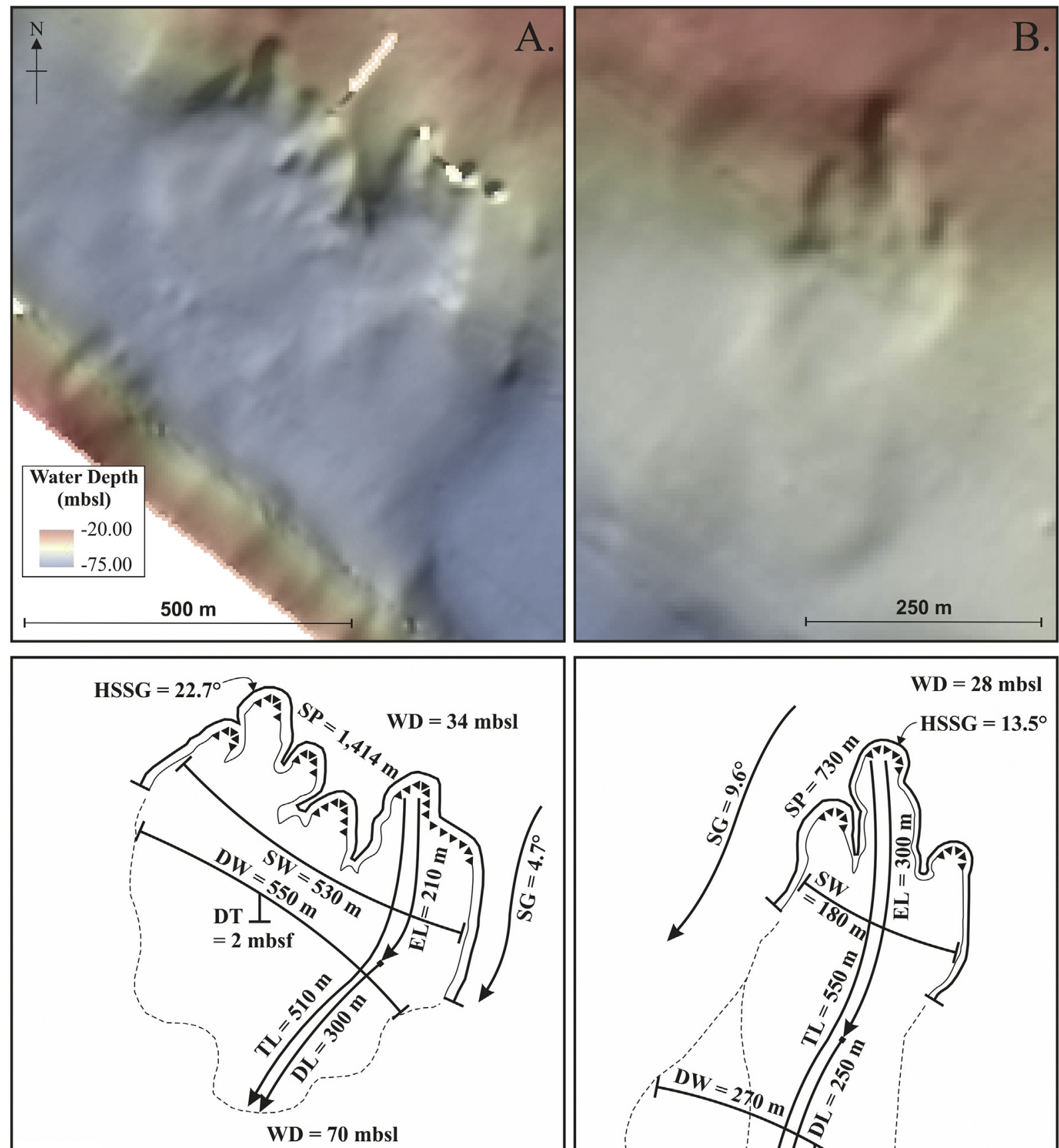

C.

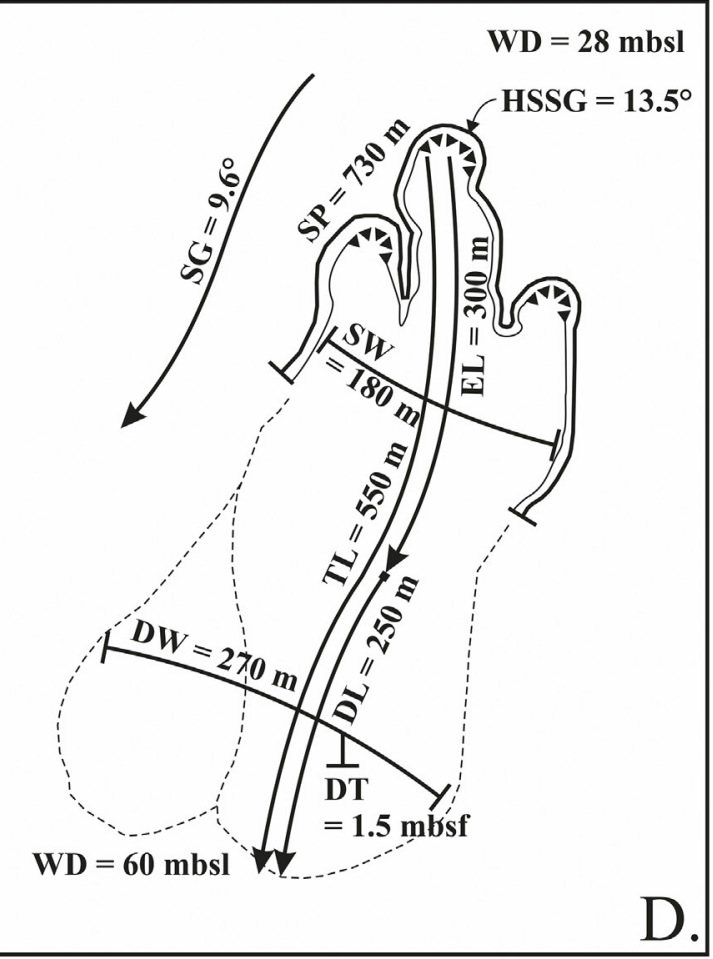

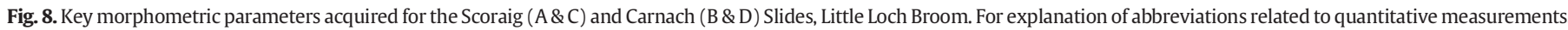
see Table 2 and caption for Fig. 4.

(Fig. 9). Headscarp heights of the scars vary between 8.5 and $10 \mathrm{~m}$, with their widths ranging up to $100 \mathrm{~m}$ and maximum evacuation lengths of $207 \mathrm{~m}$. The steep, undisturbed slope of the northeast side to the bathymetric trough has a maximum gradient of $23-30^{\circ}$ within the vicinity of the evacuation scars, compared with maximum slope gradients of the headscarps measuring up to c. $51.5^{\circ}$. The basal surfaces of all three evacuation scars exhibit a stepped, rugose profile (Fig. 9) with the Sound of Mull Slide 1 comprising up to five convex breaks in slope across the scar surface of its slope profile. Across the basin floor, to a depth of approx.
$200 \mathrm{mbsl}$, bathymetric highs are clearly visible, propagating from the base of the evacuation scars. These deposits possess convex-up profiles measuring up to $230 \mathrm{~m}$ in width and $275 \mathrm{~m}$ in length, and rise up to $6.5 \mathrm{~m}$ above the surrounding seafloor. The evacuation scars for Sound of Mull Slides 2 and 3 are very closely spaced making it difficult to distinguish between the deposits associated with these mass movement events. In addition, due to the narrow nature of the trough it is highly likely that the runout of failed material was constrained by the opposite wall of the basin. Multiple isolated blocks can be identified protruding 

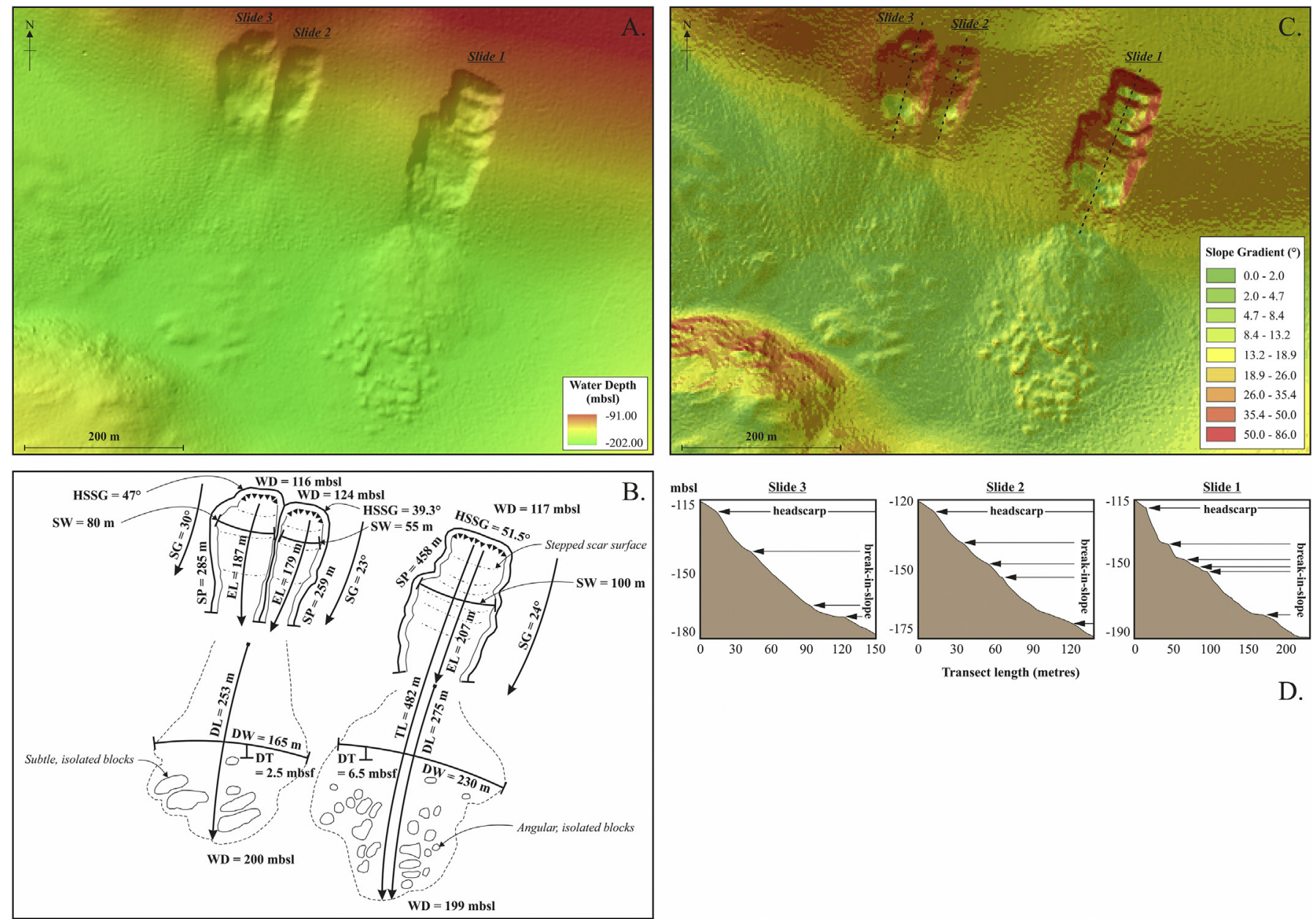

D.

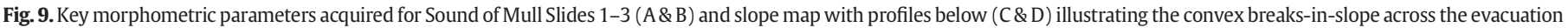
surface of each slide scar. For explanation of abbreviations related to quantitative measurements, see Table 2 and caption for Fig. 4. Multibeam data provided by UKHO/MCA.

from the surface of the mass movement deposits, marking the deposit toe of all three slides (Fig. 9). These discrete blocks appear to be more prominent and angular in nature towards the toe of Sound of Mull Slide 1 deposit when compared with those connected with the Sound of Mull Slides 2 \& 3 events. The Sound of Mull Slide 1 mobilised the bigger volume of sediments, with the calculated volume of material displaced from the evacuation area being $106,807 \mathrm{~m}^{3}, 26,752 \mathrm{~m}^{3}$ and $52,380 \mathrm{~m}^{3}$ for Sound of Mull Slides 1, 2 and 3, respectively.

\subsubsection{Southwest slope Sound of Mull, slides 4-6}

Two of the three mass movements (Slides 5 and 6 ) on the northeast facing, NW-SE trending slope of the bathymetric trough exhibit similar morphological characteristics to Sound of Mull Slides 1-3 on the opposite slope (Fig. 10). However, Slide 4 located at approx. $85 \mathrm{mbsl}$ is much larger and comprises a continuous $737 \mathrm{~m}$-long crenulated scar which can be traced for up to $362 \mathrm{~m}$ alongslope. The headscarp of this slide exhibits a slope gradient of up to $49^{\circ}$, compared with undisturbed slope gradients of $33^{\circ}$, and the evacuation scar extends for c. $176 \mathrm{~m}$ downslope to a concave break-in-slope which marks the edge of the basin floor. Unlike Sound of Mull Slides 1-3 and 5-6, which display a clear stepped profile to the basal scar surface, the evacuation scar for Slide 4 appears to be relatively smooth (Fig. 10). The area of this slide is denoted by the hummocky nature of the seafloor extending from the base of the evacuation scar for approx. $400 \mathrm{~m}$ across the trough floor to a depth of $190 \mathrm{mbsl}$. This mass movement deposit measures $305 \mathrm{~m}$ in width, and forms a (maximum) $10 \mathrm{~m}$ bathymetric high. The hummocky nature of the surface suggests that the deposit contains discrete blocks which are partially masked beneath a thin veneer of more recent sediments. In contrast the surfaces of the failed slope material from Slides 5-6 appear "fresher" and reveal the presence of isolated subangular blocks within these relatively younger mass movement deposits. The areas of failed sediments originating from the evacuation scars of Slides 5-6 are poorly defined (Fig. 10) and cannot be analysed as separate bodies without the aid of seismic profiles. Furthermore the runout distances for Slides 4-6 may be constrained by the close proximity of the opposite flank of the trough. The calculated volumes of material removed for Sound of Mull Slides 4, 5 and 6 are 456,009 $\mathrm{m}^{3}$, $22,026 \mathrm{~m}^{3}$ and $43,186 \mathrm{~m}^{3}$, respectively.

\subsection{Morphometrics of Firth of Lorn Slides}

Two seabed scars have been identified in MBES datasets between the east coast of the Isle of Mull, where the mouth of Loch Spelve meets the Firth of Lorne, and the west coast of the Isle of Kerrera (Fig. 1). Due to their proximity to the geographical features specified above, these subaqueous mass movements have been named the Outer Loch Spelve and Kerrera Slides respectively.

\subsubsection{Outer Loch Spelve Slide}

This slide occurs at a depth of $32 \mathrm{mbsl}$ on the upper southeast facing margin of a NE-SW trending trough, where a steep $\left(>50^{\circ}\right)$ bedrock slope is draped by seabed sediments (Fig. 11). The slide is marked by an arcuate scar measuring $431 \mathrm{~m}$ in length. The headwall is $3 \mathrm{~m}$-high with a gradient of $9^{\circ}$ and can be traced alongslope for approximately $241 \mathrm{~m}$ and downslope for $190 \mathrm{~m}$ along the evacuation surface. Unlike the other subaqueous landslide described in this study, the Outer Loch 

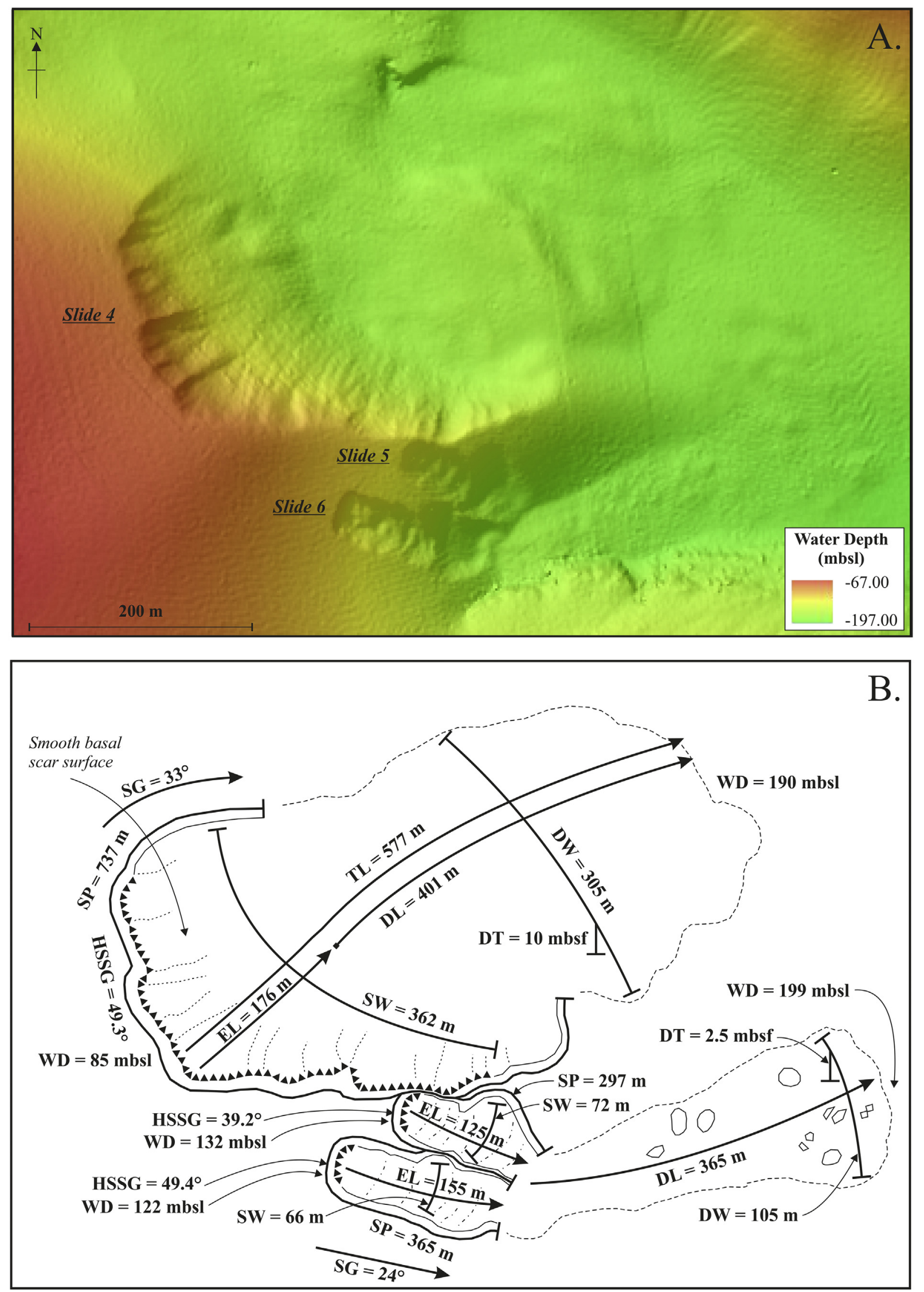

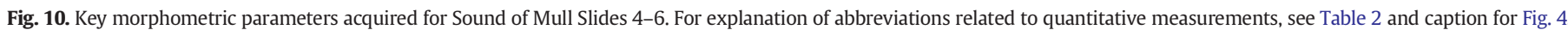
Multibeam data provided by UKHO/MCA. 

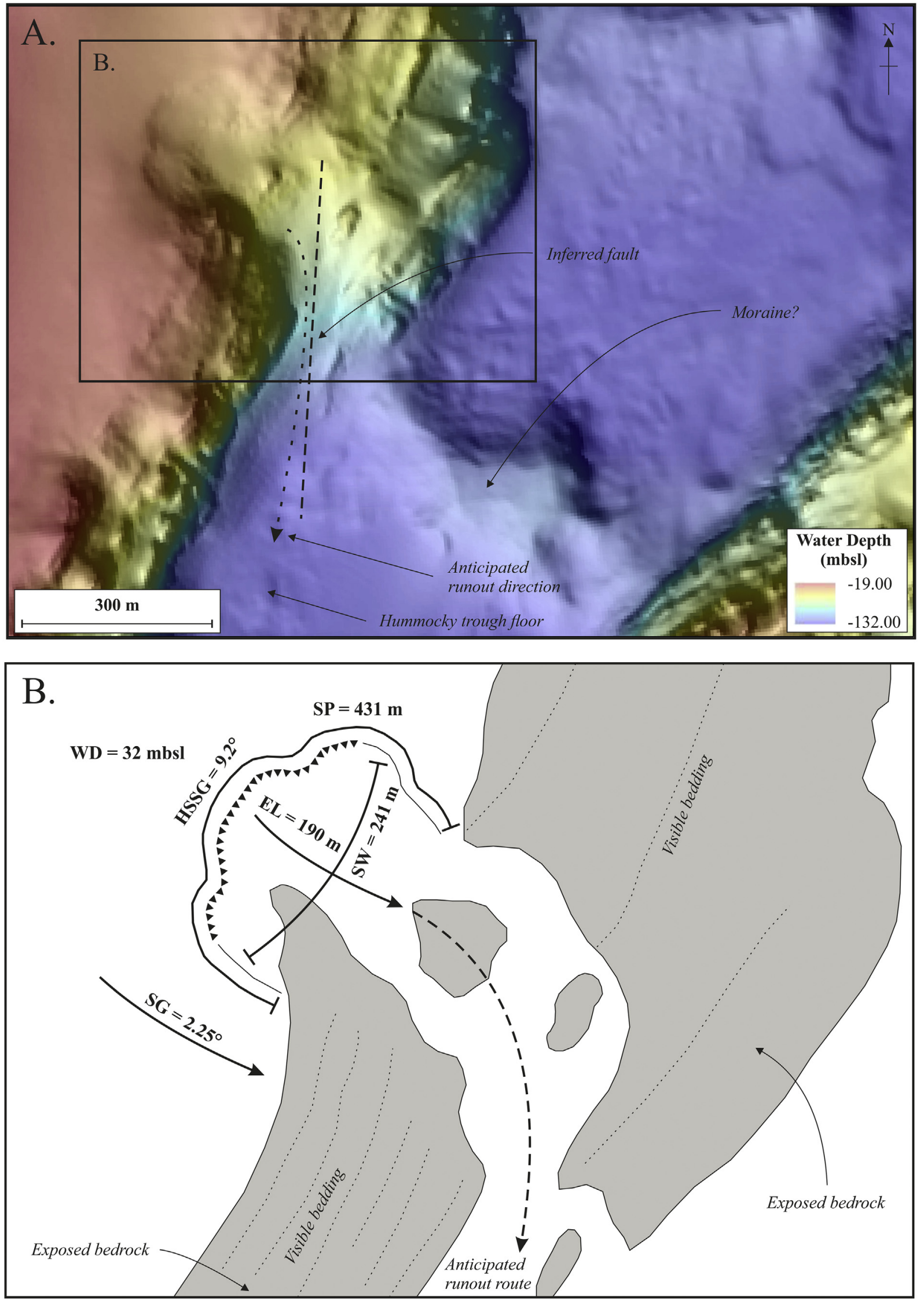

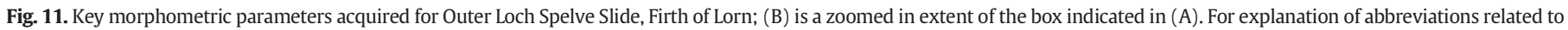
quantitative measurements, see Table 2 and caption for Fig. 4 . Multibeam data provided by SAMS. 

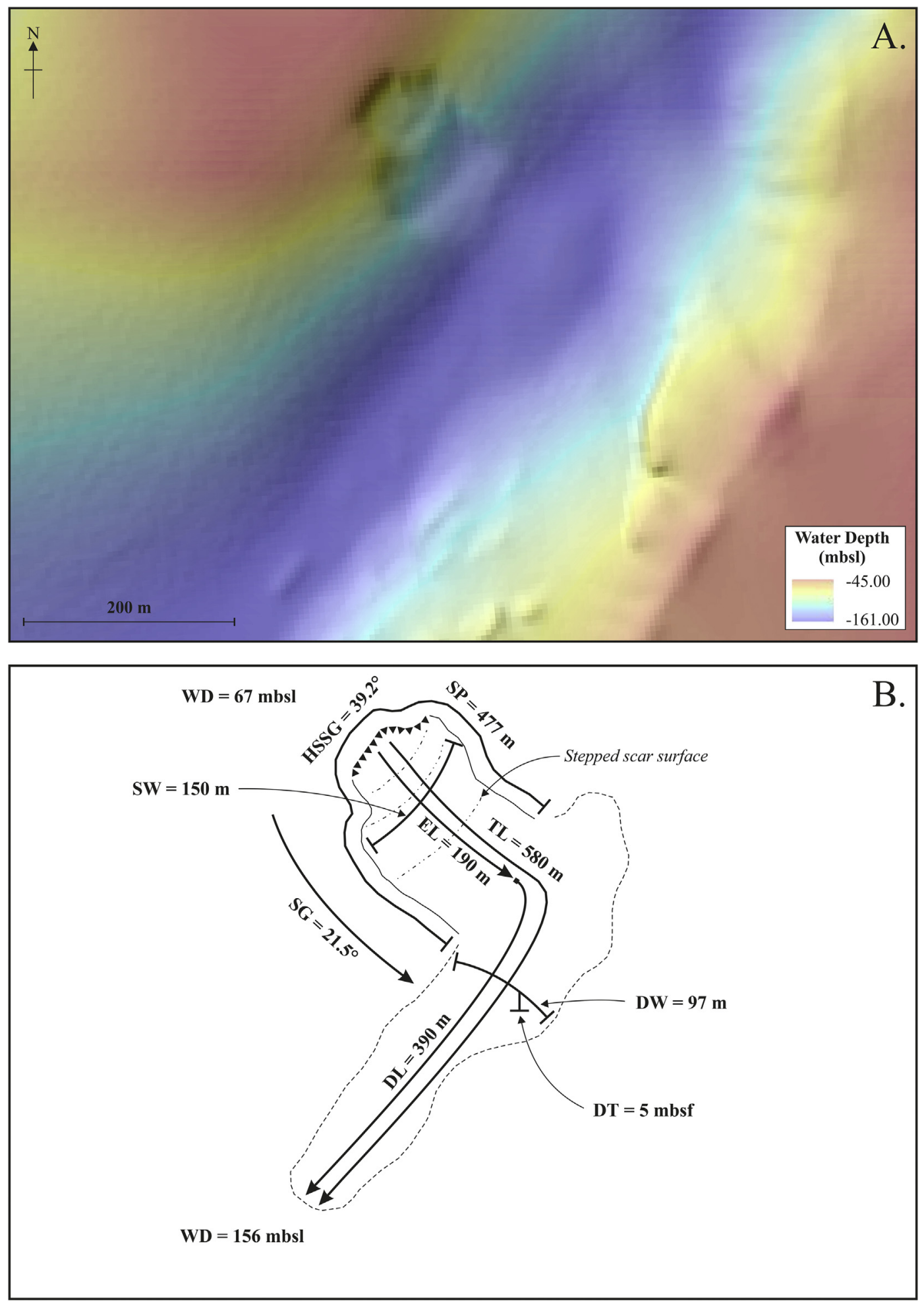

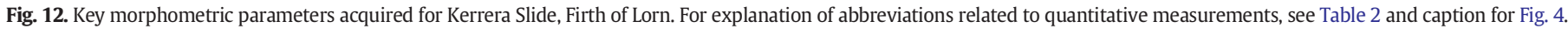
Multibeam data provided by SAMS.

Spelve Slide does not exhibit a discernible mass movement deposit; to the south of the scar, the trough floor is distinctly hummocky in nature (Fig. 11), which may potentially indicate debris beneath a later sedimentary veneer, however without the aid of sub-bottom data this cannot be confirmed. Across the wider Firth of Lorn area, the stratigraphy requires resolving to a higher resolution than what is currently available, however it does appear from the multibeam data that older hummocky materials (potentially glacigenic in nature, including debrites) are exposed at seabed in many places, however the majority are overlain by a drape of modern, likely Holocene, muds. The evacuation scar is located on a relatively gentle $\left(2.25^{\circ}\right)$ slope above a prominent rockwall which appears to have been offset by faulting immediately below the arcuate scar (Fig. 11). Although it is not possible to ascertain when faulting may have occurred at this location, it is noteworthy that this area (i.e. Isle of Mull and western Scotland) experienced fault displacement and seismic activity during the late- and post-glacial epochs, 
and in some cases as recently as c. 2000 yrs. B.P., associated with rapid isostatic rebound following deglaciation (Ringrose, 1989). A roughly NW-SE orientated bathymetric high located on the trough floor adjacent to the evacuation scar was originally thought to represent the mass movement deposit associated with the Outer Loch Spelve Slide. However, the position and orientation of this high does not fit with the expected $\mathrm{N}-\mathrm{S}$ flow geometry of any material that originated from the evacuation scar which would have been strongly influenced by the faulted-guided bedrock topography (see Fig. 11). Consequently it is concluded that the bathymetric high is likely to be a glacial landform (moraine) and therefore unrelated to the Outer Loch Spelve Slide (Fig. 11). Although the arcuate scar is well-defined, the sidewalls of the evacuation area coincide with regional changes in the slope and it was therefore not possible to reconstruct the pre-failure surface and consequently calculate the volume of material removed with any degree of confidence.

\subsubsection{Kerrera Slide}

Further NE in the Firth of Lorne, between the Isle of Mull and Isle of Kerrera, a $477 \mathrm{~m}$ scar is clearly visible incised into the unconsolidated sediments forming the southeast facing slopes of an approx. $160 \mathrm{~m}$ deep NE-SW trending trough (Fig. 12). The $12 \mathrm{~m}$-high headscarp is located at $67 \mathrm{mbsl}$ along the steep $\left(21.5^{\circ}\right) \mathrm{NW}$ slope, and has a maximum slope gradient of $39^{\circ}$. The evacuation zone extends for $190 \mathrm{~m}$ from the headscarp to the base of the slope and for $150 \mathrm{~m}$ alongslope, with a prominent stepped profile comprising three marked breaks in slope. At $156 \mathrm{mbsl}$, a hummocky $5 \mathrm{~m}$ (maximum) bathymetric high can be observed beginning at the base of the slope beneath the evacuation scar and then extending across the trough floor for approx. $390 \mathrm{~m}$ towards the SW (Fig. 12). The lateral extent of this deposit (maximum width $97 \mathrm{~m}$ ) is apparently confined to the floor of the trough by its relatively steeply sloping margins. Across the wider Firth of Lorne area, pockmarks associated with the release of shallow gas are common features on the seafloor.

It is probable that gas still remains trapped within the muddy, cohesive Quaternary deposits that blanket the underlying bedrock. The smooth slope adjacent to the Kerrera Slide provided an ideal setting to calculate the volume of material removed from the evacuation area. A total of $131,038 \mathrm{~m}^{3}$ of material are believed to have been remobilized and removed from the evacuation area during this event.

\subsection{Morphometrics of Holy Loch Slide}

Holy Loch is a small (approximately $3.5 \mathrm{~km}$ long and $1.3 \mathrm{~km}$ wide) rectangular sea loch situated at the confluence of Loch Long and the Clyde Estuary, where the estuary opens out into the Firth of Clyde (Fig. 1). The towns of Greenock and Dunoon are located approximately $11 \mathrm{~km} \mathrm{SE}$ and $3.5 \mathrm{~km} \mathrm{~S}$ of the loch, respectively.

The MBES data acquired immediately offshore of the northern coast of the loch reveals a landslide deposit characterised by a very clear blocky, tabular nature to the failed sediments (Fig. 13). Unfortunately, the survey only covers the mass movement deposit, evacuated scar surface and side scarps (the headscarp occurs outside the survey area). The minimum water depth along the top of the visible evacuated scar is $11 \mathrm{mbsl}$, with the toe of the debris lobe extending to a depth of $27 \mathrm{mbsl}$. By mapping the side scarps and the upper limit of the visible evacuation scar, a conservative scar perimeter value of $521 \mathrm{~m}$ was extracted. However this is likely to be an underestimate of the true perimeter length. The occurrence of the headscarp outside the survey area restricts the collection of a complete set of morphometric parameters (e.g. headscarp slope gradient) with both the evacuated slope length $(82 \mathrm{~m})$ and scar width $(326 \mathrm{~m})$ potentially being conservative estimates. Undisturbed slope gradients adjacent to the slide are c. $8.7^{\circ}$. The deposit, captured in its entirety by the survey data, has a width of $349 \mathrm{~m}$ alongslope and forms a $3 \mathrm{~m}$ bathymetric high (maximum) on the seafloor (Fig.
13), although evidence from sub-bottom data across the toe of the deposit clearly shows disturbance extending to depths below seabed level (Fig. $5 \mathrm{c}$ ), implying that the $3 \mathrm{~m}$ high value ascertained from the MBES data is a conservative estimate. The failed material can be traced for $240 \mathrm{~m}$ downslope from the base of the evacuation scar, and consists of discrete blocks that can rise up to c. $1.7 \mathrm{~m}$ above the surrounding debris lobe. These coherent blocks locally appear to have compressed the failed sediment mass downslope, creating positive bathymetric 'bulges' in the debris lobe immediately in front of the block. In addition, the very smooth evacuation scar surface is approximately parallel in slope profile and gradient to the surrounding undisturbed slopes. Despite the lack of bathymetric data covering the headscarp, it was felt that the pre-failure surface and volume of evacuated material could be calculated for the Holy Loch Slide, to provide a minimum or conservative estimate of transported sediment volume. Given the proximity of the slide scar to the shoreline (approx. $100 \mathrm{~m}$ ), it was concluded that the vast majority of the evacuation surface had been captured by the survey data, and it was therefore a worthwhile exercise to calculate the volume $\left(39,141 \mathrm{~m}^{3}\right)$.

\section{Implications of morphometric characteristics}

Following the collation of the morphometric parameters (Section 4) a review of the wider morphological trends and patterns across the five sites was undertaken. Key themes for global contemporaneous and former glaciomarine fjordic environments are discussed below, and their associated implications for marine infrastructure projects are investigated. Finally, potential trigger mechanisms for these geological settings are described.

\subsection{Morphometric trends and landslide types}

Although not extensive, the morphometric dataset compiled for this study (five geographical locations; 14 subaqueous mass movement events) does allow some initial comparisons and identification of potential trends in mass movement characteristics within the sea lochs of NW Scotland to be made. Four general groups of mass movement type have been identified:

- Singular Slump - a single slump event forming a relatively simple morphological feature;

- Singular Translational - comprising a singular planar failure typically forming a rectilinear scar;

- Multiple Single-Type - the amalgamation of multiple failure events of the same type (e.g. debris flow or slump) forming a single evacuation scar; and

- Complex - involving both translational and rotational failures forming one evacuation scar.

\subsubsection{Singular Slump Group}

The Singular Slump Group comprises seven subaqueous mass movement events that all exhibit morphometric characteristics associated with failure of a discrete alongslope section of seafloor slope. Whilst retrogressive failure may have resulted in upslope extension of the original evacuation scar, no evidence of further failure alongslope is visible and no headscarp modification through small-scale scalloped rotational failures has been observed. This group typically consists of relatively simple rectilinear scars, without any complex modification through amalgamation of multiple failure events. The submarine mass movement events that make up this group are Sound of Mull Slides 1-3 and 5-6, Kerrera Slide, and Outer Loch Spelve Slide.

The evacuation basal surface of these slumps can vary from stepped to smooth in profile. When comparing the evacuation scar and associated mass movement deposits of Sound of Mull Slides 1-3 (Fig. 9), varying numbers of breaks-in-slope were noted from approximately five 

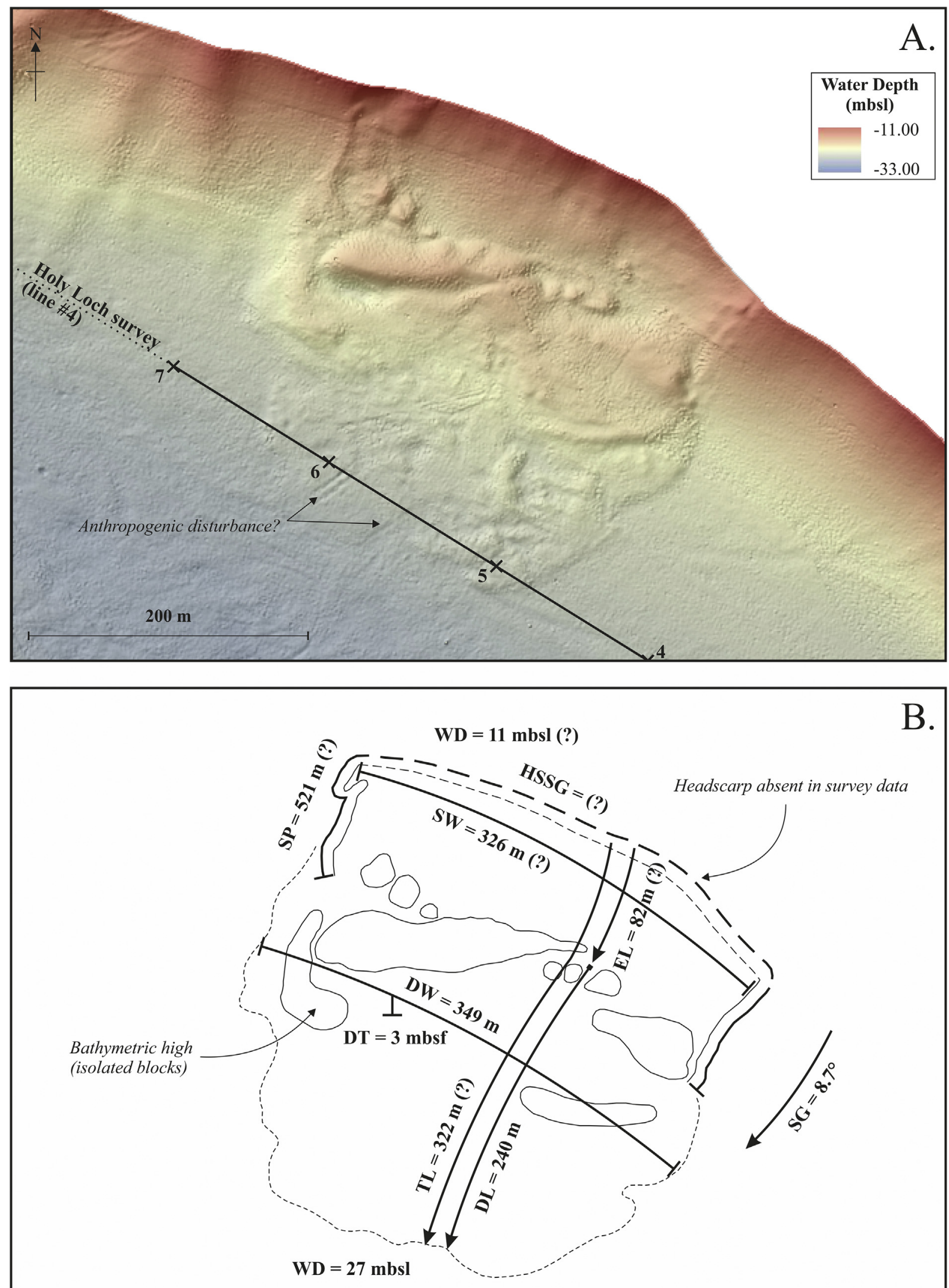

B.

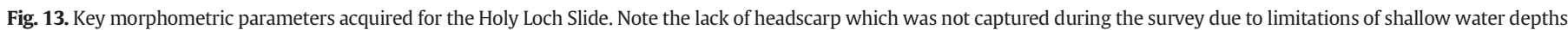
For explanation of abbreviations related to quantitative measurements, see Table 2 and caption for Fig. 4. 
Type vs Scar Perimeter

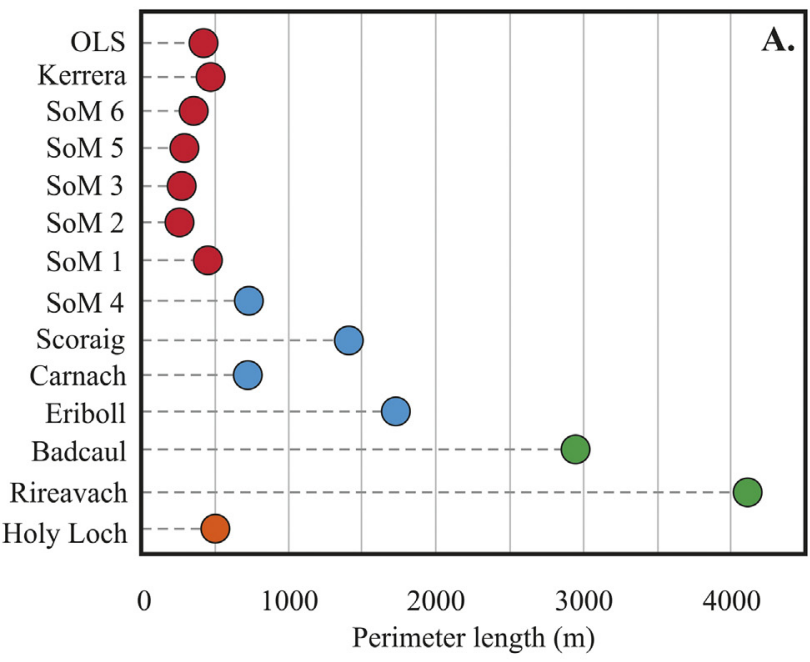

Type vs Excavation Length

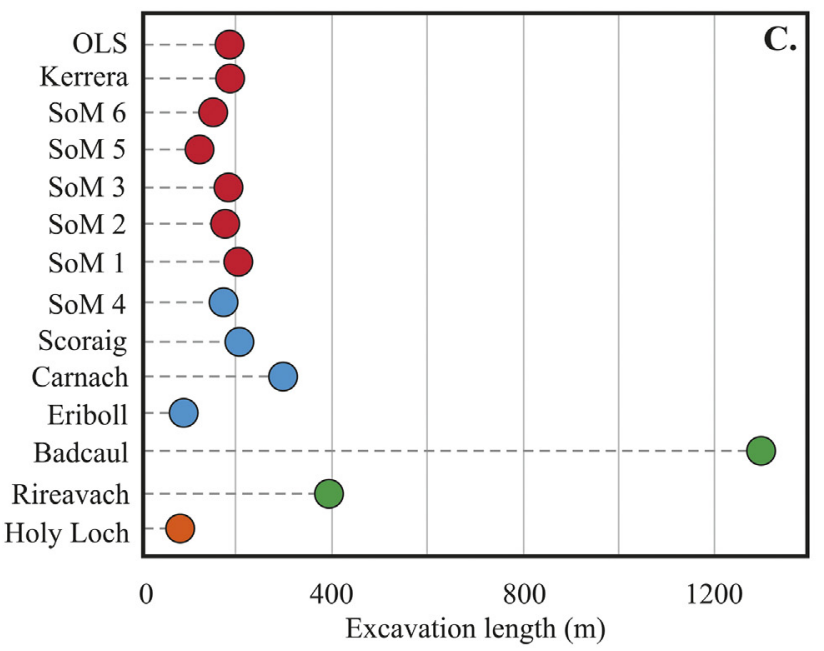

Type vs Headscarp Slope Gradient

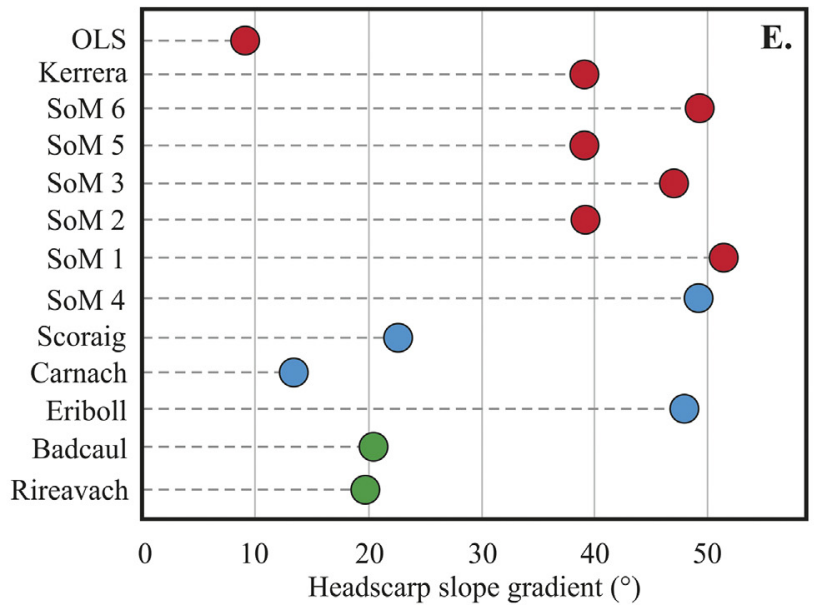

Type vs Scar Width

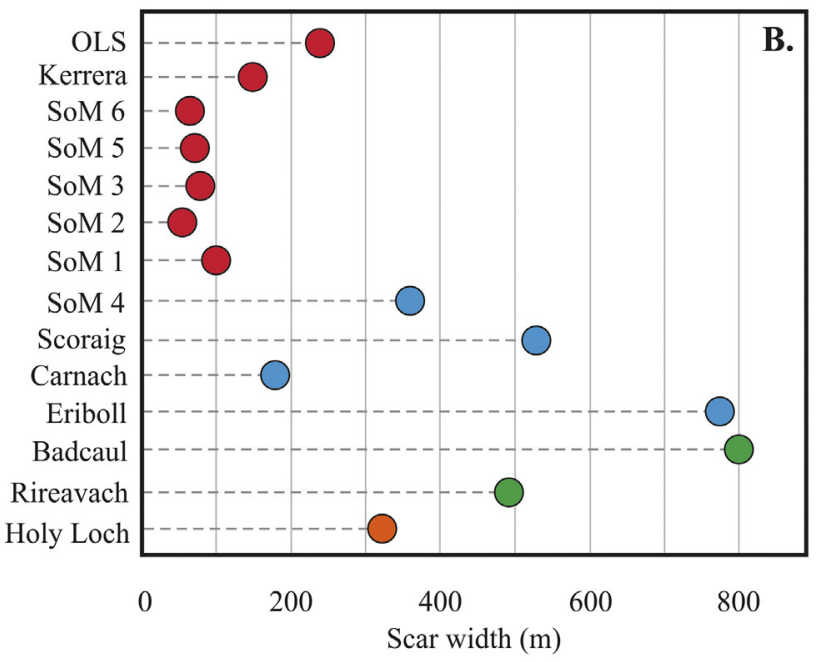

Type vs Undisturbed Slope Gradient

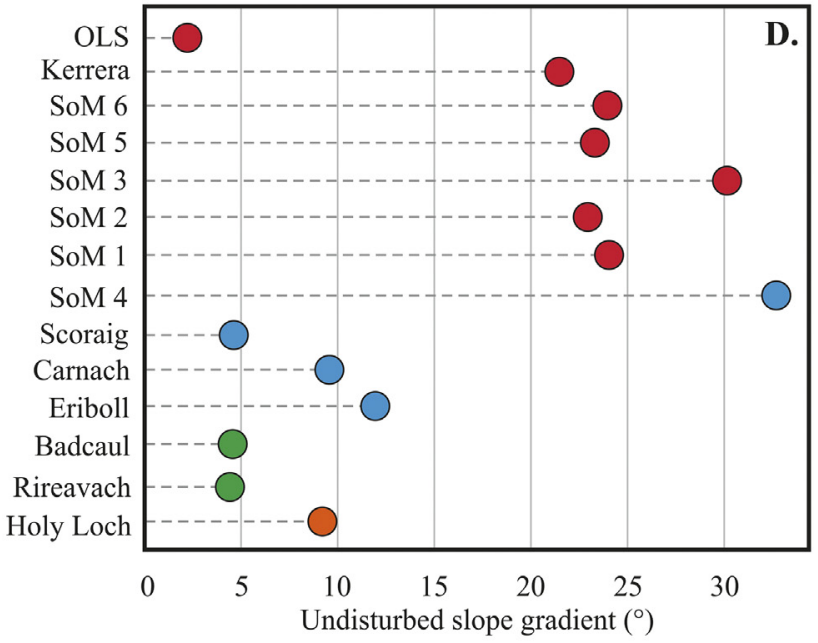

Legend

Singular Slump Group

Multiple Single-Type Group

Complex (translational \& rotational) Group

Singular Translational Group

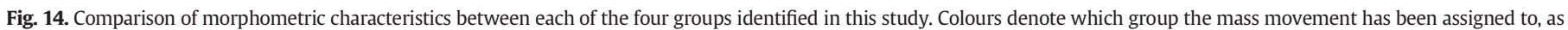
indicated by the figure legend. 
across the scar surface of Sound of Mull Slide 1 to just three across Sound of Mull Slide 3.

This is also accompanied by a difference in the appearance of the associated debris lobes, as multiple distinct subangular blocks of failed material can be observed protruding from the failed mass of Sound of Mull Slide 1 whereas the discrete blocks associated with Sound of Mull Slides 2-3 appear rounded and provide a more subtle seafloor expression, possibly suggesting a thicker covering of sediment has accumulated post-failure. This evidence has led the authors to tentatively suggest a relative chronology across these slumps; Slide 3 being the oldest failure and Slide 1 being the most recent. It is hypothesised that the increase in smoothness of the scar surface is an indication of slope modification over time, with Sound of Mull Slide 3 exhibiting a noticeably smoother appearance with more subtle (and less numerous) breaks-in-slope than Slides $1 \& 2$. In addition, the fresh appearance of the failed mass from Slide 1 (i.e. multiple subangular blocks) when compared with the subtle seafloor expressions of failed blocks from Slides 2-3 suggests that the slump deposit associated with Slide 1 has undergone less modification since deposition occurred and has a minimal post-deposition sediment cover when compared with that of the Slide 2-3 slump deposit. Unfortunately, backscatter data from across this area is not of a sufficient quality to be able to assess changes in sediment type and cover across these three mass movement deposits.

The morphometrics data for this group show the Singular Slump events to have the shortest evacuation scar perimeters (Fig. 14(A)), ranging from $259 \mathrm{~m}$ to $477 \mathrm{~m}$ in length. This is to be expected given that both the Multiple Single-Type and Complex (translational \& rotational) groups consist of slope failures that have undergone postevent modification through amalgamation of several individual evacuation scars or increased crenulation from small-scale rotational failures along the headscarp. Scar widths (Fig. 14(B)) for the Singular Slump events are also noted to be the lowest, varying between 55 and $241 \mathrm{~m}$ wide, compared with maximum scar widths of $326 \mathrm{~m}, 776 \mathrm{~m}$ and $800 \mathrm{~m}$ for the Singular Translational, Multiple Single-Type, and Complex (translational \& rotational) groups respectively. The evacuation scar lengths (Fig. 14(C)) for slumps within this group are generally relatively short, with maximum lengths of $207 \mathrm{~m}$ (Sound of Mull Slide 1) compared with $300 \mathrm{~m}$ for the Multiple Single-Type group and $1300 \mathrm{~m}$ for the Complex (translational \& rotational) group. It would appear from these results that Singular Slump events around the NW United Kingdom coast are relatively small-scale discrete landslides, which modify the subaqueous slopes to a lesser degree when compared with failures of the other groups. However, half of the mass movements that comprise this study have been assigned to this group, and therefore Singular Slumps appear to be the most commonly occurring type across the region. It should also be noted that this could be partly due to the steep-sloped enclosed basins in which the majority of the Singular Slump events have occurred; undisturbed slope gradients (Fig. 14(D)) are as high as $30^{\circ}$ (compared with $4.6^{\circ}$ for the Complex (translational \& rotational) group), resulting in higher headscarp slope gradients (Fig. 14(E)) when compared with those of the Complex (translational \& rotational) group (maximum $51.5^{\circ}$ and $20.5^{\circ}$ respectively).

\subsubsection{Singular Translational Group}

Only one submarine landslide from the available MBES dataset, the Holy Loch Slide, exhibited morphological features that indicated translational (planar) failure as the primary (and sole) mode of failure. Although the headscarp was unfortunately not captured during the Holy Loch survey due to the limitations imposed by shallow water depths, a clearly discernible evacuation scar surface can be observed incising up to $4.5 \mathrm{~m}$ into the northern slope of the loch. This slip surface is noted to be visibly smooth with no evidence of retrogressive failure (e.g. no stepped profile to the scar surface), and the slope profile and gradient of this surface reveals a subparallel nature to the adjacent undisturbed slopes. This suggests failure has occurred along a single, slope-parallel plane of weakness resulting in blocks of sediment gliding towards the basin floor. The side scarps are linear in geometry, with no evidence of post-failure modification (e.g. no small-scale scalloped depressions along the side walls). The rectilinear appearance of the scar, with a smooth, slope-parallel slip surface and unmodified linear side scarps, suggests a single translational failure event occurred along a laterally continuous plane of weakness. Whilst it should be noted that, in the absence of a visible headscarp, upslope modification through retrogressive failure and small-scale rotational failures cannot be completely excluded, based on the available multibeam data a single translational landslide event would appear to be the most likely mode of failure.

The mass movement deposit extends for approximately $240 \mathrm{~m}$ onto the basin floor and visible cohesive blocks of sediment can be seen rising above the surrounding debris lobe. It would appear that, as detachment occurred along the slope-parallel evacuation surface, segments of the failing mass broke into discrete slabs which glided downslope, ploughing frontal sediments into bathymetric mounds (or pressure ridges) within the debris lobe ahead. Given that sediment cores acquired within Holy Loch recovered homogeneous silty muds, a degree of cohesion within the failing strata is to be expected, and could explain the relatively intact slabs visible at the base of the evacuation scar.

Undertaking a comparison of certain morphometric parameters with the other subaqueous mass movements in this study was not possible given the absence of a headscarp in the MBES data for Holy Loch, for instance measuring headscarp slope gradient was impossible. However, given the apparent rectilinear geometry to the Holy Loch slide scar, the scar width is deemed to be a meaningful parameter. In this instance, the Singular Translational slide exhibits a scar width that exceeds the maximum width for any of the Singular Slump Group (326 m and $241 \mathrm{~m}$ respectively), however it is greatly exceeded by scar widths from both the Multiple Single-Type and Complex (translational \& rotational) groups which exhibit maximum scar width values of $776 \mathrm{~m}$ and $800 \mathrm{~m}$ respectively (Fig. 14(B)). Although caution should be applied to drawing conclusions from such a small dataset, it is tentatively suggested that, in the case of Holy Loch, singular translational failures appear to have the potential to impact longer sections of slope than singular slump events do, however the amalgamation of several slides resulting in a complex landslide forming will still result in a more significant section of slope being impacted, and repeated failure of the same slope section will have a larger influence on slope modification than a singular slump or translational failure will.

\subsubsection{Multiple Single-Type}

The Multiple Single-Type group (Loch Eriboll mass flows, Carnach and Scoraig Slides of Little Loch Broom, and Sound of Mull Slide 4) consists of subaqueous mass movement scars and deposits that exhibit features indicating multiple events of the same type have taken place, merging into a single feature (Figs. 4, 8 \& 10). This conclusion is supported by a continuous crenelated to scalloped headscarp displaying several incisions into the slope which feed several overlapping, but definitively separate debris lobes at the base of an evacuation scar.

The examples from NW Scotland indicate that they formed as a result of between three (Carnach Slide) to approximately ten (Loch Eriboll mass flows) individual slump or debris flow events with the incisions from these individual failure events forming a continuous amalgamated headscarp along the inclined slope. The evacuation surfaces for the Carnach, Scoraig, and Sound of Mull Slide 4 events all exhibit a smooth concave-up profile. However the Loch Eriboll mass flows possess a clear stepped profile to many (but not all) of the gullies, possibly indicating retrogressive failure has occurred whereby repeatedly failure of the headscarp for each debris flow resulted in retreat of the scar upslope leaving behind a series of steps marking the former headscarp positions along the axis of the evacuated scar. The overlapping relationship displayed between the two discrete lobes observed at the base of the Carnach Slide scar enable a relative chronology of failure to be established with the relatively younger eastern lobe crosscutting/overlapping the western lobe (see Fig. 8). The adjacent Scoraig Slide also 
exhibits several bathymetric highs at the base of the scar which indicate the location of the mass movement deposits. In this instance, the MBES data does not provide any indication of relative chronology for the slump deposits as no overlap between the bathymetric highs was observed and backscatter data did not highlight any difference in sediment composition or thickness of cover across the deposits. Similarly, the Loch Eriboll deposit is clearly a combination of several distinct failure events, with raised ridges running perpendicular to the slope contours bounding the individual debris lobes. This evidence of multiple deposits at the base of the slope supports the hypothesis that the evacuation scars in this group comprise several failure events.

The scar perimeters for this group (Fig. 14(A)) exhibit a range of values from $730 \mathrm{~m}$ (Carnach Slide) to $1735 \mathrm{~m}$ (Loch Eriboll). Unsurprisingly, these values exceed the maximum perimeter lengths for any of the events within the Singular Slump group (maximum $477 \mathrm{~m}$ ) as multiple headscarps have merged to increase the overall scar perimeter lengths for the Multiple Single-Type landslides. It is likely that the amalgamation of multiple scars is also responsible for the higher scar width (Fig. 14(B)) values (maximum 776 m, Loch Eriboll) when the Multiple Single-Type group is compared with the slope failures of the Singular Slump group (maximum $241 \mathrm{~m}$, Outer Loch Spelve Slide). This process of merging singular failure events appears to have a significant impact on the morphometric values for the scar perimeter and width parameters, however the evacuation lengths (Fig. 14(C)) for events within both the Singular Slump (125-207 m) and Multiple Single-Type (93-300 m) groups do not appear meaningfully different. This illustrates that, when considering the mass movement events comprising this study, amalgamation of multiple failure scars extensively modifies the alongslope profile but not the upslope profile and, as a new failure event impacts upon an existing scar, this does not appear to initiate further retrogressive failure upslope of the pre-existing headscarp.

\subsubsection{Complex (translational \& rotational)}

Examples of this group include the Rireavach and Badcaul Slides of Little Loch Broom (Figs. 6-7). These slides exhibit primary rectilinear scars that have been modified as a result of small-scale scallop-shaped rotational slumping along the headscarp and side scarps. Stoker et al. (Stoker et al., 2010) noted the presence of inclined and gently tilted, intact blocks of laminated clay within these slide deposits, and argued that these represent glided blocks that ultimately failed under gravitational stresses following a period of creep. While the rectilinear scarp profiles and relatively subplanar evacuation scar surfaces suggest translational failure, the scallop-shaped rotational failures along the headscarps and side scarps have modified the morphology of the evacuation area and thus these sides represent complex failure types. This classification is further strengthened by subsurface (boomer) profiles across the evacuation scar surface (along-axis) of the Badcaul Slide (Fig. 5b), where internal reflectors associated with undisturbed (pre-failure) sediments consisting of homogeneous to laminated soft clay and silty clay reveal a general tabular structure with reflectors dripping into the basin (c.f. (Stoker et al., 2010)). However, the scar surface has been modified by shallow back-tilted blocks (e.g. Fig. 5b), whereby rotation is evident from internal reflectors dipping back into the slope in the seismic profiles (Stoker et al., 2010).

The scars associated with the complex failure types exhibit perimeter lengths that far exceed those of slumps and debris flows (both singular and multiple), as well as single translational failures (Fig. 14(A)) with values ranging from between 2950 and $4100 \mathrm{~m}$ in length. These large scar perimeter lengths could be attributed to the modification and repeated failure of the slopes following the initial failure event. Both examples in this group display modification of the rectilinear headscarp through small-scale scalloped rotational failures which increased the scar perimeter. Both slides clearly show at least two major sources of failed slope (e.g. the northern re-entrant and eastern reentrant in the case of the Rireavach Slide) suggesting that more than one phase of failure occurred, followed by subsequent extension of the original scar perimeter. In addition, these failures are developed on relatively low gradient $\left(4.5-4.6^{\circ}\right)$, undisturbed slope when compared to failures typical of the other groups (Fig. 14(D)). This could be partially controlled by the local stratigraphy. For example laminated muds and clays gently dipping out of the slope face and into the basin could be conducive to translational failure, whereby intact blocks fail under gravitational stresses and glide from the evacuation area to the basin floor (Stoker et al., 2010). In addition local environmental and hydrodynamic conditions may also be factors controlling this complex style of failure.

\subsection{Implications for glaciomarine coastal settings}

This study adds to the wealth of evidence relating to subaqueous mass movements and their consequences within glacial and paraglacial, nearshore fjordic settings. Numerous studies have detailed submarine slides in fjords and coastal inlets of countries that are synonymous with past and present glaciated environments, including areas of Canada, Norway, Svalbard, and Alaska (e.g. Bøe et al., 2004; Brouard \& Lajeunesse, 2019; Forwick \& Vorren, 2012; Lee et al., 2006; L'Heureux et al., 2010; Parsons et al., 2014; Prior et al., 1981; Syvitski \& Schafer, 1996; Vardy et al., 2012). However, this study is the first comprehensive collection of morphometric data relating to submarine slope failures in the UK, and emphasises that glacial conditioning of slopes (for example, oversteepened troughs) and the subsequent deposition of glacial and glaciomarine sediments can result in similar slope stability issues developing in fjords of lower latitudes to those exhibited across high-latitude areas. In Scotland, complete deglaciation is thought to have occurred between 12.2 and 11.5 ka BP (Bromley et al., 2014; Peacock \& Rose, 2017; Small \& Fabel, 2016), further emphasising that glacial conditioning of subaqueous slopes can have an influence on stability long after glacial retreat has taken place, and that the conditions under which these sediments have been deposited are likely to contribute significantly to ongoing instability issues.

Fjords, embayments and shallow inlets have historically been successful sites for human settlement due to the natural protection they provide for ports and harbours. In recent times, as subsea and coastal engineering has advanced, these locations have also been favoured as landfall sites for subsea cables and pipelines, sites for aquaculture industry installations, and continued waterfront development (both residential and industrial). However, for the reasons outlined in several studies (e.g. (Lee et al., 2006; L'Heureux et al., 2010; Parsons et al., 2014; Vardy et al., 2012)), the submerged slopes of a fjordic domain can pose a significant hazard to infrastructure and even life. The diverse styles of slope failure identified in this study, based on a relatively small dataset, provides additional evidence of the issues surrounding subaqueous slope instability within coastal and fjordic environments, and further strengthens the need for robust and thorough site investigation and characterisation prior to any nearshore infrastructure project commencing.

\subsection{Trigger mechanisms in fjord E' coastal settings}

The dataset used for this study consists of multibeam bathymetry covering various geographical areas off the NW coast of the United Kingdom. As physical samples (e.g. sediment cores through failed units) and extensive sub-bottom data are not available for the slides identified in this study, ascertaining trigger mechanisms with a high degree of certainty is difficult. However, by considering morphological features present across the sites, and the general geo-environmental settings in which these subaqueous mass movement events have occurred, potential trigger mechanisms can be inferred and discussed (Fig. 15).

Although the stratigraphy immediately surrounding each failure scar cannot be known without undertaking a sediment coring campaign, BGS open-source core data has been investigated to provide a general overview of ground conditions within close proximity to each 
study area. Sediments across each site are characteristic of deposition under glacial, glaciomarine, and marine environments, with predominant lithological units varying from homogeneous silty shelly muds (Loch Eriboll, Sound of Mull and Holy Loch) to pebbly, gravelly sandy grey plastic clay (Little Loch Broom and Kerrera / Outer Loch Spelve). As detailed in Section 2 "Geological and environmental setting", these sedimentary units have been deposited under conditions associated with periods of glaciation and glacial-retreat which can have adverse effects on subaqueous slope stability. High rates of deposition are synonymous with fjord environments, with rapid sedimentation resulting from downwasting glaciers leading to high pore pressures, underconsolidation and associated low shear strengths (Hampton et al., 1996; Urlaub et al., 2013). Fjords, by their very nature, are glacially oversteepened basins with both terrestrial and submerged slopes exhibiting generally high slope gradients; another factor that can contribute to subaqueous mass movement events, when retreating ice results in debutressing of steep slopes and increased gravitational stresses (Stoker et al., 2010). The Rireavach and Badcaul Slides of Little Loch Broom are the only events from this dataset that have previously been dated, with the onset of mass failure occurring around 14-13 ka BP coinciding with glacial downwasting and retreat during the Lateglacial interval (Stoker et al., 2010).

The above scenario can be exacerbated when steep, unsupported slopes composed of these rapidly deposited sediments are exposed to seismic loading associated with glacio-isostatic readjustment. Firth and Stewart (Firth \& Stewart, 2000) suggest that the period during and immediately following deglaciation in Scotland was more seismically active than the mid to Late Holocene, and crustal uplift in the areas surrounding many of the reported subaqueous mass movements is ongoing at present albeit at a reduced rate (e.g. $1.8 \mathrm{~mm} / \mathrm{yr}$ around the Firth of Clyde, area of the Holy Loch slide, and $1.0 \mathrm{~mm} / \mathrm{yr}$ at Moidart, approx. $22 \mathrm{~km}$ NE of the Sound of Mull slides). Indeed, the link between post-glacial earthquake activity and seafloor slumping has already been made for the area of the Summer Isles, where the Little Loch Broom subaqueous mass movements occurred (e.g. (Stoker \& Bradwell, 2009)), and it would be reasonable to assume that seismic loading associated with glacio-isostatic readjustment may be a contributing factor to all the slope failures covered in this study. It should be noted that other seismic sources are present around dynamic ice fronts, including ice calving events which have the capability to produce magnitude $M$ $\geq 5.0$ shallow earthquakes, and cannot be discounted as potential trigger mechanisms (Ekström \& Stark, 2013; Nettles \& Ekström, 2010).

Another source of loading on shallow submarine slopes is cyclic loading induced by wave action, whereby dynamic pressures on the seafloor created by wave migration results in pore water pressure fluctuations within marine sediments and can even initiate liquefaction (Jeng, 2001; Owen et al., 2007). Studies have shown that storm wave action on Holocene glaciomarine sediments in water depths of $<35 \mathrm{~m}$ around the continental shelf of Northeast Gulf of Alaska can have the ability to generate greater shear stresses than those created by earthquake events (Schwab \& Lee, 1983). Within fjords of British Columbia, wave modelling has shown that storm waves can contribute significantly to slope failures within typically non-cohesive sediment accumulations along delta fronts (Kostaschuk \& McCann, 1989). However, a prominent feature of fjord systems that can have a controlling influence over storm wave propagation within a fjord is the presence (or absence) of an entrance sill. Where a fjord is relatively narrow and an entrance sill is present, storm wave energy is likely to be absorbed at the fjord mouth, however large storm waves can be propagated for several kilometres up-fjord in more open inlets, particularly where no entrance

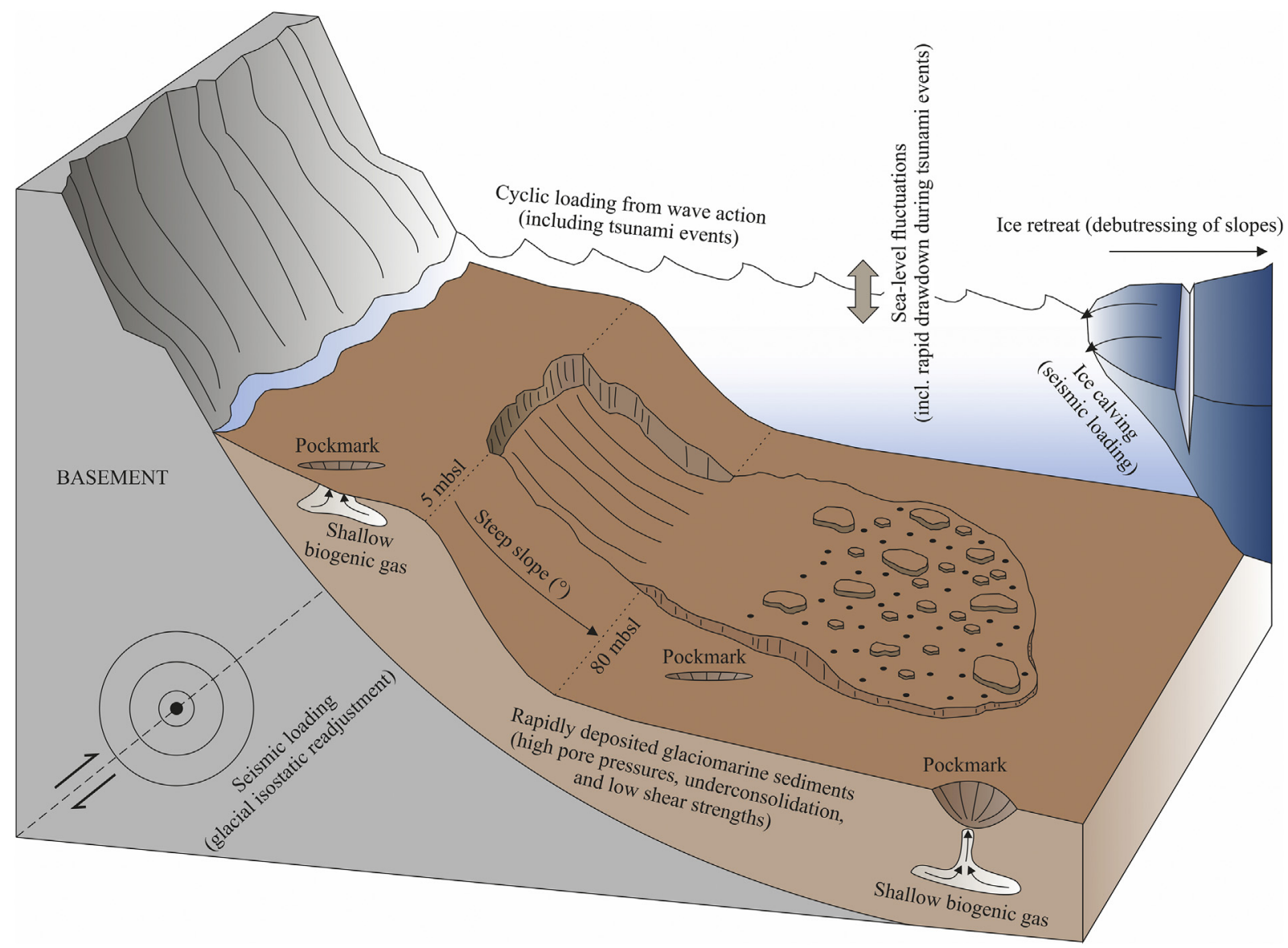

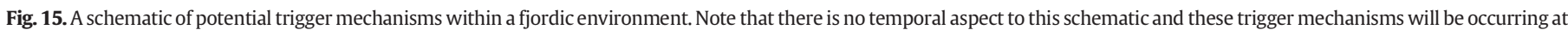
different stages of deglaciation and post-deglaciation (e.g. debutressing will not be occurring at the same time as shallow gas expulsion). 

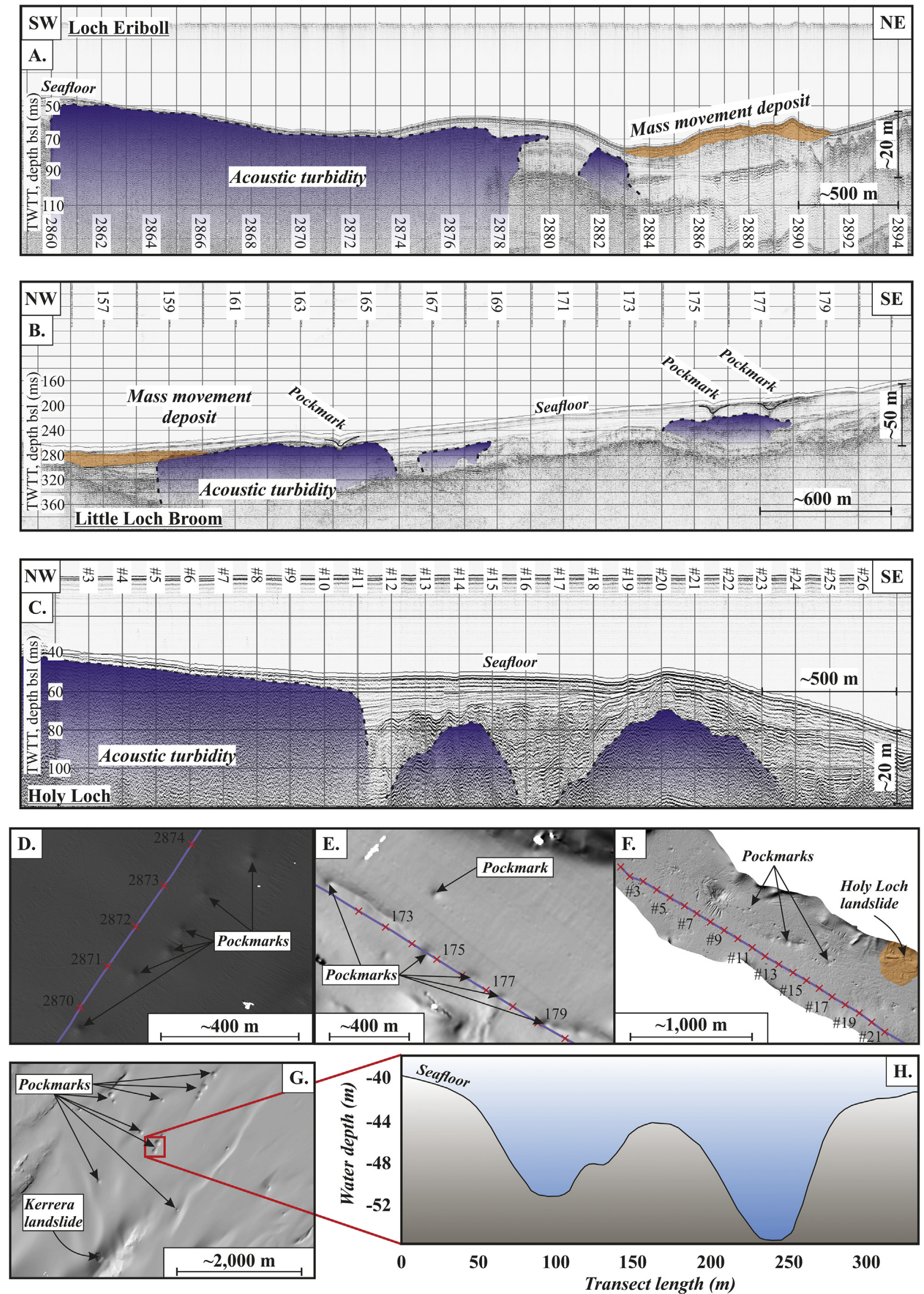


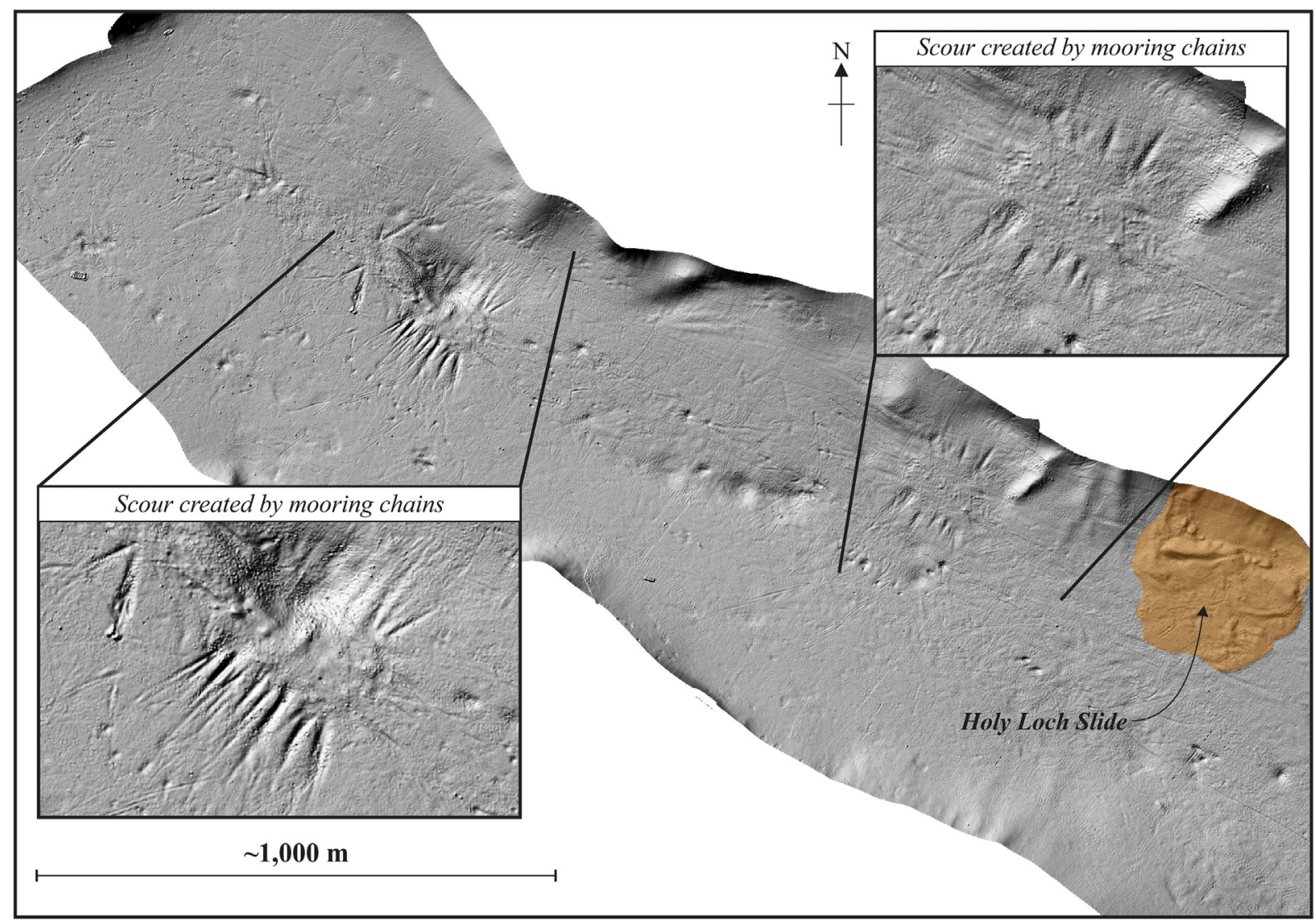

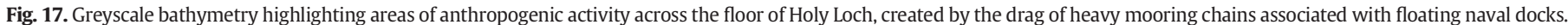
Orange polygon highlights the area of the Holy Loch Slide.

sill is present (Pickrill, 1987; Powell \& Molnia, 1989). Given the relatively confined, narrow geometries of the fjords that comprise this study, and taking into consideration the generally cohesive nature of the sediments that form the shallow subsurface of the subaqueous slopes, it is deemed unlikely that storm wave loading will have been a significant trigger mechanism. In addition, many of the mass movements have occurred within fjords that exhibit entrance sills (e.g. Little Loch Broom), and the slope failures that have occurred within more open inlets appear to be at depths below anticipated storm wave base (e.g. Sound of Mull slumps have a minimum water depth of $85 \mathrm{mbsl}$ for the headscarps).

However, wave action associated with the Storegga tsunami (approx. 8100 cal. Yrs. BP) may have been responsible for the debris flow complex within Loch Eriboll. Approaching tsunami waves can exert significant hydrodynamic pressures on seafloor slopes and the rapid drawdown of water levels that often occurs immediately prior to a tsunami wave making landfall can remove the confining forces on shallow sediments, potentially producing undrained loading conditions which have a detrimental effect on slope stability (Owen et al., 2007; Wright \& Rathje, 2003). At Loch Eriboll evidence of the Storegga tsunami can be found in the form of a 5-10 cm-thick grey well sorted sand bed exhibiting an erosional lower contact which has been recovered in coastal cores and dated to almost exactly the same age as the Storegga landslide and tsunami event (Long et al., 2016). Long et al. (Long et al., 2016) also reconstruct late glacial and Holocene relative sea-level changes in the vicinity of Loch Eriboll, and conclude that water levels would be in the region of $6.0 \mathrm{~m}$ lower than present-day levels around the time of the Storegga tsunami, and therefore the shallowest section of the headscarp (as established through this study) would have been approximately $2.0 \mathrm{mbsl}$ around 8000 cal. Yrs. BP. As a result, the Storegga tsunami event is suggested as a potential trigger mechanism for the Loch Eriboll mass flows; however, without age constraints around the failure event, this cannot be definitively confirmed.

A prominent geomorphic feature across many of the sites (e.g. Little Loch Broom, Loch Eriboll, Holy Loch, and Kerrera Slide) are seafloor pockmarks created by fluid and/or biogenic gas expulsion at seabed (Fig. 16). The decay of organic matter within rapidly deposited sediments can result in the generation of bubble-phase gas which, in turn, can generate elevated pore water pressures and reduced shear strength in overlying strata, contributing to overall slope instability (Berndt et al., 2012; Best et al., 2003; Lee et al., 2007; Nisbet \& Piper, 1998; Urgeles \& Camerlenghi, 2013; Urlaub et al., 2013). During periods of sea-level rise/ fall, the stress regime controlling the stability of gas-rich sediments can be negatively influenced. Overpressure can develop as sea-level falls, as pore pressures reduce less than the total stress due to the highly compressible nature of gassy soils (Urlaub et al., 2013). Conversely, during sea-level rise, effective stress can increase in gassy sediments leading to a reduction in slope stability (Urlaub et al., 2013). It should also be noted that, in addition to evidence of gas/fluid expulsion at seabed (i.e. pockmarks) in multibeam data, acoustic turbidity and blanking has been observed in seismic profiles surrounding many of the sites

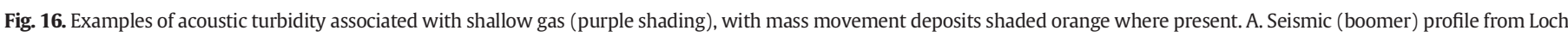

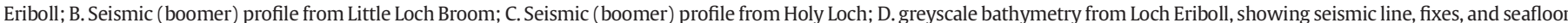

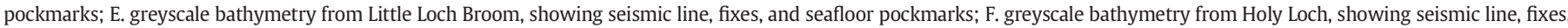

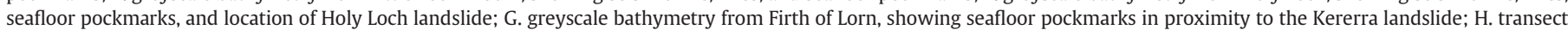
profile from across two seafloor pockmarks located near the Kerrera Slide, location indicated by the red box on G. 
covered by this study (e.g. Fig. 16), which is often associated with shallow gas-charged sediments (e.g. (Stoker et al., 2010)).

Finally, a common feature of coastal and fjordic settings which can have detrimental impacts on nearshore slope stability is anthropogenic engineering and modification of the coastline. There have been several cases of subaqueous slope failures that have been directly linked to human activity and onshore development; for instance, the 1996 landslide near Finneidfjord, Norway, may have been triggered by engineering works (e.g. loading the upper slope though placement of fill or blasting for road construction) along the coastline (Vardy et al., 2012). Similarly, recent submarine landslides at the Nidelva fjord delta, Central Norway, may be attributed to anthropogenic activities such as vibrations caused by construction works and embankment fillings loading the slope (L'Heureux et al., 2010). Whilst the vast majority of the sites included in this study do not have significantly developed coastlines, and have been exposed to minimal anthropogenic activity, Holy Loch in the Outer Clyde Estuary is an exception. The loch was used as a naval base during World War I, and then as a United States (US) navy submarine base for $>30$ years with the US military remaining until 1992 (Chapman et al., 2001; Miller et al., 2000). Evidence of this can still be observed on the seafloor, where linear scour marks created by heavy mooring chains secured to the floating naval docks (Fig. 17) are visible in multibeam data (Chapman et al., 2001).

It would be reasonable to assume that, in a relatively compact, shallow inlet like Holy Loch, navy vessels would have made contact with the seafloor numerous times particularly in the nearshore zone. In addition, following the withdrawal of US navy personnel, a large-scale clean-up operation was undertaken to remove the considerable volume of military debris (e.g. scrap metal) littering the loch floor using barges, remotely operated vehicles (ROVs), magnets, and grab equipment (Chapman et al., 2001; Miller et al., 2000). This intense seafloor activity may also have negatively impacted the soft, muddy subaqueous slopes and could have potentially triggered the shallow translational failure observed in the multibeam data.

\section{Limitations \& further work}

It is important to acknowledge that the above results and discussions are based on a relatively small dataset, with a total of 14 mass movements incorporated into this study. However, it is hoped that this study can contribute to the literature pool concerning morphometric parameters of submarine landslides around the United Kingdom Continental Shelf and beyond, as advocated by Clare et al. (Clare et al., 2018), in an attempt to identify trends that may aid in our understanding of where subaqueous mass movements occur and whether there are any controlling morphological parameters dictating the distribution of events.

The above assessment of morphometric parameters was also limited to a MBES dataset as high-quality seismic was not available for the majority of the sites. In addition, the multibeam datasets were of varying resolutions as they were provided by many different data sources and collected for different purposes (see Table 1). This limits the study somewhat as some morphometric parameters (e.g. volume and deposit thickness) are better obtained using subsurface data, where available (Clare et al., 2018). Further work includes expanding the database with more mass movement events to create a more statistically robust comparison. Further survey work is required to recover sediment cores through the slide deposits and adjacent undisturbed slopes, to obtain further ground-truthing of the conclusions drawn from this study. In addition, the acquisition of sediment cores may allow for crucial dating of failed sediments, as it is currently unclear how recent many of these mass movement events occurred.

\section{Conclusions}

A dataset of 14 discrete subaqueous mass movement scars and deposits was compiled from multibeam echo sounder (MBES) surveys around the United Kingdom northwest coast. Survey data were primarily collected in fjords (known locally as sea lochs), coastal inlets and channels between the islands of the Inner Hebrides, where sediment distribution has been dominated by glacial and glaciomarine depositional processes.

Following analysis of the MBES dataset, a database of morphometric parameters was compiled and comparisons between the morphology of each mass movement was undertaken. It was concluded that four distinct groups of subaqueous landslides could be created, with similarities is morphometric parameters and geometries of evacuation scars defining each group. These groups were:

- Singular Slump Group - this group includes seven mass movements from the Sound of Mull and Firth of Lorn. These slumps exhibit simple geometries, typically with a single arcuate headscarp and no evidence of alongslope modification or merging of multiple scars. Despite the group being labelled as singular events, it should be noted that evidence of upslope modification was noted in the form of stepped profiles to the basal surface of evacuation scars, suggesting retrogressive failure may have occurred.

- Singular Translational Group - only one failure scar from the MBES dataset was determined to have been formed through translational (planar) failure alone, with no evidence of post-failure modification through small-scale rotational failures of the scar perimeter or merging of adjacent (but distinctly separate) failure events. This was located in the Holy Loch, where the basal surface of the evacuation scar was noted to be smooth and relatively linear (i.e. not concave as one would expect of rotational failure scar surfaces). This scar surface was sub-parallel in profile to the adjacent undisturbed slope, giving the impression of a single slope-parallel plane of weakness along which sediments failed and cohesive blocks glided towards the basin floor.

- Multiple Single-Type Group - mass movement scars and deposits that have characteristics associated with multiple debris flow or slump events impacting adjacent sections of slope, resulting in the amalgamation of individual scars into a single, crenulated scar encompassing multiple arcuate headscarps. Downslope, the deposits associated with this group may display evidence of overlapping debris lobes, reinforcing the interpretation that several events have occurred at this single geographical point, resulting in the modification of the evacuation scar. From this study, four subaqueous mass movements were assigned to this group; the debris flows within Loch Eriboll, a fjord on the north coast of Scotland, two failure events within Little Loch Broom, and one slope failure from the steep slopes of a seafloor basin in the Sound of Mull.

- Complex (translational \& rotational) Group - landslides that exhibit morphological evidence of both translational and rotational failure occurring across a single evacuation scar. In the current dataset, this comprised two subaqueous mass movements from within the fjord of Little Loch Broom.

Several potential trigger mechanisms were tentatively suggested, primarily through observations of the fjordic and shallow inlet settings in which these subaqueous mass movements have taken place. It was noted that shallow gas (likely to be of biogenic origin) was prevalent across the majority of the sites, perhaps contributing to slope instability, and an intriguing possible link between the Storegga tsunami event and the Loch Eriboll mass failure requires further investigation through the acquisition and dating of core material through the failed sediments. Other potential failure mechanisms relate to the wider fjordic environ- 
ment under which these sediments were deposited (e.g. rapid sedimentation rates and glacio-isostatic readjustment).

It is acknowledged that this study could be built up with the addition of sediment cores through the mass failure deposits and adjacent undisturbed slopes. In particular, dating of failure events is crucial to understanding the risk these events may pose to nearshore infrastructure projects (e.g. subsea cable landfall sites) in the future.

Additional MBES data are needed to expand this database, in order to create a more statistically robust study, as advocated by (Clare et al., 2018). However, it is hoped that this work can be built upon and will contribute to further, wider studies of subaqueous mass movements and correlations between morphometric parameters.

\section{Declaration of competing interest}

The authors declare that they have no known competing financial interests or personal relationships that could have appeared to influence the work reported in this paper.

\section{Acknowledgements}

The authors are grateful to all data providers (BGS, SAMS, and UKHO/MCA) for allowing access to relevant MBES datasets, without which this study would not have been possible. Many thanks to Prof. Yongqiang Zong (editor) and two anonymous reviewers for their constructive and positive feedback which helped to improve the paper. Thanks to British Geological Survey internal reviewer (Emrys Phillips) for his useful and constructive feedback. We are grateful to Diego Diaz Doce (BGS) for contributing to the methodology used for calculating landslide volumes, and Kirstin Johnson (BGS) for discussions around the limited seismic dataset. David Tappin and Martyn Stoker (BGS) are thanked for their useful discussions at the initial project concept stage. Gareth Carter, Rhys Cooper, Joana Gafeira, and David Long publish with permission of the Director of the British Geological Survey (United Kingdom Research and Innovation).

\section{References}

Arosio, R., Dove, D., Cofaigh, C.Ó., Howe, J.A., 2018. Submarine deglacial sediment and geomorphological record of southwestern Scotland after the Last Glacial Maximum. Mar. Geol. 403, 62-79.

Ballantyne, C.K., Dawson, S., Dick, R., Fabel, D., Kralikaite, E., Milne, F., Sandeman, G.F., Xu, S., 2018. The coastal landslides of Shetland. Scott. Geogr. J. 1-26.

Baltzer, A., Holmes, R., Evans, D., 1998. Debris flows on the Sula Sgeir Fan, NW of Scotland. Geol. Soc. Lond., Spec. Publ. 129 (1), 105-115.

Berndt, C., Costa, S., Canals, M., Camerlenghi, A., de Mol, B., Saunders, M., 2012. Repeated slope failure linked to fluid migration: the Ana submarine landslide complex, Eivissa Channel, Western Mediterranean Sea. Earth Planet. Sci. Lett. 319, 65-74.

Best, A.I., Clayton, C.R.I., Longva, O., Szuman, M., 2003. The role of free gas in the activation of submarine slides in Finneidfjord. In: Locat, J., Mienert, J., Boisvert, L. (Eds.), Submarine Mass Movements and Their Consequences. Springer, Netherlands, pp. 491-498.

Bøe, R., Longva, O., Lepland, A., Blikra, L.H., Sønstegaard, E., Haflidason, H., Bryn, P., Lien, R., 2004. Postglacial mass movements and their causes in fjords and lakes in western Norway. Nor. J. Geol. 84, 35-55.

Bromley, G.R., Putnam, A.E., Rademaker, K.M., Lowell, T.V., Schaefer, J.M., Hall, B., Winckler, G., Birkel, S.D., Borns, H.W., 2014. Younger Dryas deglaciation of Scotland driven by warming summers. Proc. Natl. Acad. Sci. 111 (17), 6215-6219.

Brouard, E., Lajeunesse, P., 2019. Glacial to postglacial submarine landform assemblages in fiords of northeastern Baffin Island. Geomorphology 330, 40-56.

Bulat, J., 2005. Some considerations on the interpretation of seabed images based on commercial 3D seismic in the Faroe-Shetland Channel. Basin Res. 17 (1), 21-42.

Carter, L., Gavey, R., Talling, P., Liu, J., 2014. Insights into submarine geohazards from breaks in subsea telecommunication cables. Oceanography 27 (2), 58-67.

Chapman, P., Wills, D., Brookes, G., 2001. Real-time visualization in the offshore industry. IEEE Comput. Graph. Appl. 21 (4), 6-10.

Clare, M., Chaytor, J., Dabson, O., Gamboa, D., Georgiopoulou, A., Eady, H., Hunt, J., Jackson, C., Katz, O., Krastel, S., León, R., Micallef, A., Moernaut, J., Moriconi, R., Moscardelli, L., Mueller, C., Normandeau, A., Patacci, M., Steventon, M., Urlaub, M., Völker, D., Wood, L., Jobe, Z., 2018. A consistent global approach for the morphometric characterization of subaqueous landslides. Geol. Soc. Lond., Spec. Publ. 477, SP477-15.

Dix, J.K., Duck, R.W., 2000. A high-resolution seismic stratigraphy from a Scottish sea loch and its implications for Loch Lomond Stadial deglaciation. J. Quat. Sci. 15 (6), 645-656.
Dove, D., Arosio, R., Finlayson, A., Bradwell, T., Howe, J.A., 2015. Submarine glacial landforms record Late Pleistocene ice-sheet dynamics, Inner Hebrides, Scotland. Quat. Sci. Rev. 123, 76-90.

Ekström, G., Stark, C.P., 2013. Simple scaling of catastrophic landslide dynamics. Science 339 (6126), 1416-1419.

Evans, D., Harrison, Z., Shannon, P.M., Laberg, J.S., Nielsen, T., Ayers, S., Holmes, R., Hoult, R. J., Lindberg, B., Haflidason, H., Long, D., Kuijpers, A., Andersen, E.S., Bryn, P., 2005 Palaeoslides and other mass failures of Pliocene to Pleistocene age along the Atlantic continental margin of NW Europe. Mar. Pet. Geol. 22 (9), 1131-1148.

Farrow, G.E., 1983. Recent sediments and sedimentation in the Inner Hebrides. 83 pp. 91-105.

Firth, C.R., Stewart, I.S., 2000. Postglacial tectonics of the Scottish glacio-isostatic uplift centre. Quat. Sci. Rev. 19 (14-15), 1469-1493.

Forwick, M., Vorren, T.O., 2012. Submarine mass wasting in Isfjorden, Spitsbergen. In: Yamada, Y., Kawamura, K., Ikehara, K., Ogawa, Y., Urgeles, R., Mosher, D., Chaytor, J. Strasser, M. (Eds.), Submarine Mass Movements and Their Consequences. Springer, Netherlands, pp. 711-722.

Fyfe, J.A., Long, D., Evans, D., 1993. United Kingdom Offshore Regional Report: The Geology of the Malin-Hebrides Sea Area. HMSO for the British Geological Survey, London.

Gallois, R.W., 2011. A fossil landslide preserved offshore at Lyme Regis, Dorset, UK. Geoscience in South-West England 12, 329-334.

Glimsdal, S., L'Heureux, J.S., Harbitz, C.B., Løvholt, F., 2016. The $29^{\text {th }}$ January 2014 submarine landslide at Statland, Norway-landslide dynamics, tsunami generation, and runup. Landslides 13 (6), 1435-1444.

Hampton, M.A., Lee, H.J., Locat, J., 1996. Submarine landslides. Rev. Geophys. 34 (1), 33-59.

Holmes, R., Long, D., Dodd, L.R., 1998. Large-scale debrites and submarine landslides on the Barra Fan, west of Britain. Geol. Soc. Lond., Spec. Publ. 129 (1), 67-79.

Howe, J.A., Shimmield, T., Austin, W.E., Longva, O., 2002. Post-glacial depositional environments in a mid-high latitude glacially-overdeepened sea loch, inner loch Etive, western Scotland. Mar. Geol. 185 (3-4), 417-433.

Howe, J.A., Dove, D., Bradwell, T., Gafeira, J., 2012. Submarine geomorphology and glacial history of the Sea of the Hebrides, UK. Mar. Geol. 315, 64-76.

Howe, J.A., Anderton, R., Arosio, R., Dove, D., Bradwell, T., Crump, P., Cooper, R., Cocuccio A., 2015. The seabed geomorphology and geological structure of the Firth of Lorn, western Scotland, UK, as revealed by multibeam echo-sounder survey. Earth and Environmental Science Transactions of the Royal Society of Edinburgh 105 (4), 273-284.

Hungr, O., Leroueil, S., Picarelli, L., 2014. The Varnes classification of landslide types, an update. Landslides 11 (2), 167-194.

Jackson, P.D., Gunn, D.A., Long, D., 2004. Predicting variability in the stability of slope sediments due to earthquake ground motion in the AFEN area of the western UK continental shelf. Mar. Geol. 213 (1), 363-378.

Jeng, D.S., 2001. Mechanism of the wave-induced seabed instability in the vicinity of a breakwater: a review. Ocean Eng. 28 (5), 537-570.

Kostaschuk, R., McCann, S., 1989. Submarine slope stability of a fjord delta: Bella Coola, British Columbia. Géog. Phys. Quatern. 43 (1), 87-95.

Lee, H., Ryan, H., Kayen, R.E., Haeussler, P.J., Dartnell, P., Hampton, M.A., 2006. Varieties of submarine failure morphologies of seismically-induced landslides in Alaskan fjords Nor. J. Geol. 86, 221-230.

Lee, H.J., Locat, J., Desgagnés, P., Parsons, J.D., McAdoo, B.G., Orange, D.L., Puig, P., Wong, F. L., Dartnell, P., Boulanger, E., 2007. Submarine mass movements on continental margins. In: Nittrouer, C.A., Austin, J.A., Field, M.E., Kravitz, J.H., Syvitski, J.P.M., Wiberg, P. L. (Eds.), Continental Margin Sedimentation: From Sediment Transport to Sequence Stratigraphy. Blackwell Publishing Ltd., Oxford, UK.

L'Heureux, J.S., Hansen, L., Longva, O., Emdal, A., Grande, L., 2010. A multidisciplinary study of submarine landslides at the Nidelva fjord delta, Central Norway-implications for geohazards assessments. Nor. J. Geol. 90 (1-2), 1-20.

Locat, J., Martin, F., Levesque, C., Locat, P., Leroueil, S., Konrad, J.M., Urgeles, R., Canals, M., Duchesne, M.J., 2003. Submarine mass movements in the upper Saguenay Fjord, (Québec, Canada), triggered by the 1663 earthquake. In: Locat, J., Mienert, J., Boisvert, L. (Eds.), Submarine Mass Movements and Their Consequences. Springer, Netherlands, pp. 509-519.

Long. D. Stevenson, A.G. Wilson, C.K. Bulat, J. 2003. Slope failures in the Faroe-Shetland Channel. In: Locat, J., Mienert, J., Boisvert, L. (Eds.), Submarine Mass Movements and Their Consequences. Springer, Netherlands, pp. 281-289.

Long, A.J., Barlow, N.L., Dawson, S., Hill, J., Innes, J.B., Kelham, C., Milne, F.D., Dawson, A., 2016. Lateglacial and Holocene relative sea-level changes and first evidence for the Storegga tsunami in Sutherland, Scotland. J. Quat. Sci. 31 (3), 239-255.

Longva, O., Janbu, N., Blikra, L.H., Bøe, R., 2003. The 1996 Finneidfjord slide; seafloor failure and slide dynamics. In: Locat, J., Mienert, J., Boisvert, L. (Eds.), Submarine Mass Movements and Their Consequences. Springer, Netherlands, pp. 531-538.

Miller, B.S., Pirie, D.J., Redshaw, C.J., 2000. An assessment of the contamination and toxicity of marine sediments in the Holy Loch, Scotland. Mar. Pollut. Bull. 40 (1), 22-35.

Nettles, M., Ekström, G., 2010. Glacial earthquakes in Greenland and Antarctica. Annu. Rev. Earth Planet. Sci. 38, 467-491.

Nisbet, E.G., Piper, D.J., 1998. Giant submarine landslides. Nature 392 (6674), 329

Owen, M., Day, S., Maslin, M., 2007. Late Pleistocene submarine mass movements: occurrence and causes. Quat. Sci. Rev. 26 (7-8), 958-978.

Parsons, T., Geist, E.L., Ryan, H.F., Lee, H.J., Haeussler, P.J., Lynett, P., Hart, P.E., Sliter, R., Roland, E., 2014. Source and progression of a submarine landslide and tsunami: the 1964 Great Alaska earthquake at Valdez. Journal of Geophysical Research: Solid Earth 119 (11), 8502-8516.

Peacock, J.D., Rose, J., 2017. Was the Younger Dryas (Loch Lomond Stadial) icefield on Rannoch Moor, western Scotland, deglaciated as early as c. 12.5 cal ka BP? Proc. Geol. Assoc. 128 (2), 173-179. 
Peacock, J.D., Horne, D.J., Whittaker, J.E., 2012. Late Devensian evolution of the marine offshore environment of western Scotland. Proc. Geol. Assoc. 123 (3), 419-437.

Pickrill, R.A., 1987. Circulation and sedimentation of suspended particulate matter in New Zealand fjords. Mar. Geol. 74 (1-2), 21-39.

Powell, R.D., Molnia, B.F., 1989. Glacimarine sedimentary processes, facies and morphology of the south-southeast Alaska shelf and fjords. Mar. Geol. 85 (2-4), 359-390.

Prior, D.B., Wiseman Jr., W.J., Bryant, W.R., 1981. Submarine chutes on the slopes of fjord deltas. Nature 290 (5804), 326.

Ringrose, P.S., 1989. Recent fault movement and palaeoseismicity in western Scotland Tectonophysics 163 (3-4), 305-314.

Schwab, W.C., Lee, H.J., 1983. Geotechnical analyses of submarine landslides in glacial marine sediment, northeast gulf of Alaska. In: Molnia, B.F. (Ed.), Glacial-Marine Sedimentation. Springer, Boston, USA, pp. 145-184.

Small, D., Fabel, D., 2016. Was Scotland deglaciated during the younger Dryas? Quat. Sci. Rev. 145, 259-263.

Stoker, M., Bradwell, T., 2009. Neotectonic deformation in a Scottish fjord, Loch Broom, NW Scotland. Scott. J. Geol. 45 (2), 107-116.

Stoker, M., Bradwell, T., Wilson, C., Harper, C., Smith, D., Brett, C., 2006. Pristine fjor landsystem revealed on the sea bed in the Summer Isles region, NW Scotland. Scott. J. Geol. 42 (2), 89-99.

Stoker, M.S., Bradwell, T., Howe, J.A., Wilkinson, I.P., McIntyre, K., 2009. Lateglacial ice-cap dynamics in NW Scotland: evidence from the fjords of the Summer Isles region. Quat Sci. Rev. 28 (27-28), 3161-3184.
Stoker, M.S., Wilson, C.R., Howe, J.A., Bradwell, T., Long, D., 2010. Paraglacial slope instability in Scottish fjords: examples from Little Loch Broom, NW Scotland. Geol. Soc. Lond., Spec. Publ. 344 (1), 225-242.

Syvitski, J.P., Schafer, C.T., 1996. Evidence for an earthquake-triggered basin collapse in Saguenay Fjord, Canada. Sediment. Geol. 104 (1-4), 127-153.

Ten Brink, U.S., Geist, E.L., Andrews, B.D., 2006. Size distribution of submarine landslides and its implication to tsunami hazard in Puerto Rico. Geophys. Res. Lett. 33 (11)

Urgeles, R Camerlenghi, A, 2013. Submarine landslides of the Mediterranean Sea: Trigger mechanisms, dynamics, and frequency-magnitude distribution. Journal of Geophysical Research: Earth Surface 118 (4), 2600-2618.

Urlaub, M., Talling, P.J., Masson, D.G., 2013. Timing and frequency of large submarine landslides: implications for understanding triggers and future geohazard. Quat. Sci. Rev. 72, 63-82.

Vardy, M.E., L'Heureux, J.S., Vanneste, M., Longva, O., Steiner, A., Forsberg, C.F., Haflidason, H., Brendryen, J., 2012. Multidisciplinary investigation of a shallow near-shore landslide, Finneidfjord, Norway. Near Surface Geophysics 10 (4), 267-277.

Wright, S.G., Rathje, E.M., 2003. Triggering mechanisms of slope instability and their relationship to earthquakes and tsunamis. Pure Appl. Geophys. 160 (10-11), 1865-1877. 